\title{
An Updated Global Species Diversity and Phylogeny in the Genus Wickerhamomyces with Addition of Two New Species from Thailand
}

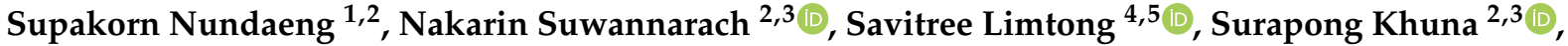 \\ Jaturong Kumla $2,3, *$ (i) and Saisamorn Lumyong $2,3,5, *$ (i)
}

check for

updates

Citation: Nundaeng, S.;

Suwannarach, N.; Limtong, S.; Khuna,

S.; Kumla, J.; Lumyong, S. An

Updated Global Species Diversity

and Phylogeny in the Genus

Wickerhamomyces with Addition of Two New Species from Thailand. J.

Fungi 2021, 7, 957. https://doi.org/ 10.3390/jof7110957

Academic Editors: Anush Kosakyan, Rodica Catana and Alona Biketova

Received: 14 October 2021

Accepted: 8 November 2021

Published: 11 November 2021

Publisher's Note: MDPI stays neutral with regard to jurisdictional claims in published maps and institutional affiliations.

Copyright: (c) 2021 by the authors. Licensee MDPI, Basel, Switzerland. This article is an open access article distributed under the terms and conditions of the Creative Commons Attribution (CC BY) license (https:/ / creativecommons.org/licenses/by/ $4.0 /)$.
1 Master of Science Program in Applied Microbiology (International Program), Faculty of Science, Chiang Mai University, Chiang Mai 50200, Thailand; Supakorn.ning@gmail.com

2 Department of Biology, Faculty of Science, Chiang Mai University, Chiang Mai 50200, Thailand; suwan.462@gmail.com (N.S.); Trio_9@hotmail.com (S.K.)

3 Research Center of Microbial Diversity and Sustainable Utilization, Chiang Mai University, Chiang Mai 50200, Thailand

4 Department of Microbiology, Faculty of Science, Kasetsart University, Bangkok 10900, Thailand; fscistl@ku.ac.th

5 Academy of Science, The Royal Society of Thailand, Bangkok 10300, Thailand

* Correspondence: Jaturong_yai@hotmail.com (J.K.); scboi009@gmail.com (S.L.); Tel.: +66-81-881-3658 (S.L.)

\begin{abstract}
Ascomycetous yeast species in the genus Wickerhamomyces (Saccharomycetales, Wickerhamomycetaceae) are isolated from various habitats and distributed throughout the world. Prior to this study, 35 species had been validly published and accepted into this genus. Beneficially, Wickerhamomyces species have been used in a number of biotechnologically applications of environment, food, beverage industries, biofuel, medicine and agriculture. However, in some studies, Wickerhamomyces species have been identified as an opportunistic human pathogen. Through an overview of diversity, taxonomy and recently published literature, we have updated a brief review of Wickerhamomyces. Moreover, two new Wickerhamomyces species were isolated from the soil samples of Assam tea (Camellia sinensis var. assamica) that were collected from plantations in northern Thailand. Herein, we have identified these species as W. lannaensis and W. nanensis. The identification of these species was based on phenotypic (morphological, biochemical and physiological characteristics) and molecular analyses. Phylogenetic analyses of a combination of the internal transcribed spacer (ITS) region and the D1/D2 domains of the large subunit (LSU) of ribosomal DNA genes support that $W$. lannaensis and W. nanensis are distinct from other species within the genus Wickerhamomyces. A full description, illustrations and a phylogenetic tree showing the position of both new species have been provided. Accordingly, a new combination species, W. myanmarensis has been proposed based on the phylogenetic results. A new key for species identification is provided.
\end{abstract}

Keywords: ascomycetous yeast; distribution; new species; phylogeny; taxonomy; Wickerhamomyces

\section{Introduction}

The genus Wickerhamomyces was first proposed by Kurtzman et al. [1] in 2008 with W. canadensis (basionym Hansenula canadensis) as the type species. This genus belongs to the family Wickerhamomycetaceae of the order Saccharomycetales [1]. Wickerhamomyces species can reproduce both asexually and sexually. Through asexual reproduction, the species reproduce by budding and some species produce pseudohyphae and/or true hyphae. Alternatively, in sexual reproduction they produce hat-shaped or spherical ascospores with an equatorial ledge for sexual reproduction [1,2]. Most of the known Wickerhamomyces species can utilize various carbon sources, but not methanol or hexadecane. Nitrate utilization was observed in some species, while the diazonium blue B reaction was 
negative for all species. The predominant ubiquinone in the Wickerhamomyces species is CoQ-7 [1,3].

Most species of the genus Wickerhamomyces have been transferred from the genera Candida, Hansenula, Pichia and Williopsis based on phylogenetic analyses [1,2,4-6]. Currently, a total of 35 species have been accepted and recorded in the Index Fungorum [7]. A phylogenetic study of Arastehfar et al. [8] has suggested that Pichai myanmarensis [9] should be transferred to the genus Wickerhamomyces, but W. myanmarensis has remained invalidly published. Therefore, in this study, we have proposed the validation of this name for a new combination species. In this case, 35 type species of Wickerhamomyces and $P$. myanmarensis have been reported since 1891 . It has been revealed that the highest number of the Wickerhamomyces species were discovered during the period of 2011-2020, followed by the period of 1951-1960 (6 species), the period of 1971-1980 (4 species) and the period of 2001-2010 (3 species) (Figure 1). An increasing trend with regard to the discovery of new species of Wickerhamomyces is expected to continue in the future. Wickerhamomyces species are widely distributed in tropical, subtropical, temperate and subpolar areas throughout the world (Figure 2). It has been reported that the highest number of Wickerhamomyces species were found in Asia (18 species), followed by Europe (12 species), South America (8 species), Africa (7 species), North America (3 species), Oceania (1 species) and Antartica (1 species) [7-82] (Table 1). Both W. anomalus and W. onychis are known to be from Asia, Africa, Europe and South America [13-35,54-59]. Moreover, W. anomalus and W. rabaulenis have been discovered in Antarctica (King George Island) [17] and Oceania (Papua New Guinea) [67], respectively. Recently, W. psychrolipolyticus has been discovered from Japan [65]. Consequently, Wickerhamomyces species have been successfully isolated from various habitats, as has been summarized in Table 1.

Many species of Wickerhamomyces have been used in a variety of industries including the medicinal, agricultural, biofuel, food and beverage industries, and a number of others [64]. Most previous studies have focused on different strains of W. anomalus for biotechnological applications. For example, the W. anomalus strains CBS261, HN006 and HN010 are capable of excessively producing ethyl acetate. As a result, this species has been used in the brewing of Baijiu (Chinese liquor) and in winemaking to improve the aroma and quality of the finished product [83-85].

Wickerhamomyces anomalus strains BS91 and DMKU-RP04 could effectively inhibit plant pathogenic fungi and have been used as a biological control agent in agriculture [86-88]. Notably, W. anomalus strains SDBR-CMU-S1-06 and Wa-32 have exhibited plant growth promotion potential by solubilizing insoluble minerals, producing indole-3-acitic acid (IAA) and siderophores, and by secreting various extracellular enzymes [16,89]. Moreover, most strains of $W$. anomalus are known to produce killer toxins that possess antimicrobial and larvicidal activities [90,91]. Wickerhamomyces bovis and W. silvicola have been observed to produce mycocin, which exhibited fungicidal activity [92,93]. In addition, W. lynferdii and $W$. sydowiorum have been recognized as relevant yeast species for the improvement of the fermentation processes for coffee cherries and cocoa, respectively [79,94]. Furthermore, W. subpelliculosus has been used as an alternative to baker's yeast [95], while $W$. chambardii could produce amylase and cellulase enzymes that could be used to produce bioethanol from corn straw $[96,97]$. Previous studies have found that the biosurfactants produced by $W$. anomalus and $W$. edaphicus $[47,98,99]$, the saturated fatty acids produced by W. siamensis [100], xylitol produced by W. rabaulensis [101], cellulase enzymes produced by W. psychrolipolyticus [65] and the extracellular polysaccharide produced by $W$. mucosus [102] could be applied in the bioremediation, biotechnological and cosmetic industries. Furthermore, these substances could also be employed in the production of detergents, food and various pharmaceuticals, as well as in the process of oil recovery enhancement.

On the other hand, some Wickerhamomyces species (e.g., W. anomalus and W. lynferdii) have been responsible for the spoilage of beer and bakery products [103-106]. Some cases of human infection caused by $W$. anomalus, $W$. myanmarensis and $W$. onychis have also been reported, but only with patients with serious illness [8,107-111]. Based on this evidence, 
W. anomalus has been labeled a biosafety level 1 organism by the European Food Safety Authority [112] and is considered safe for consumption by healthy individuals.

Currently, only eight Wickerhamomyces species, namely W. anomalus, W. ciferrii, W. edaphicus, W. rabaulensis, $W$. siamensis, $W$. sydowiorum, $W$. tratensis and $W$. xylosicus, have been reported in Thailand $[4,8,16,17,19,20,46,70,78]$. Accordingly, Thailand has been identified as a hotspot for unexpected novel species and the newly recorded discovery of many microorganisms $[113,114]$. In our previous investigation on yeasts in soil samples collected from Assam tea (Camellia sinensis var. assamica) plantations in northern Thailand [16], we obtained five yeast strains belonged to the genus Wickerhamomyces that represent potentially new species. In our present study, we have described them into two novel species. These two novel species are introduced based on their phenotypic (morphological, biochemical and physiological data) and molecular characteristics. To confirm their taxonomic status, phylogenetic relationship was determined by analysis of the combined sequence dataset of the D1/D2 domains of LSU and ITS sequences.

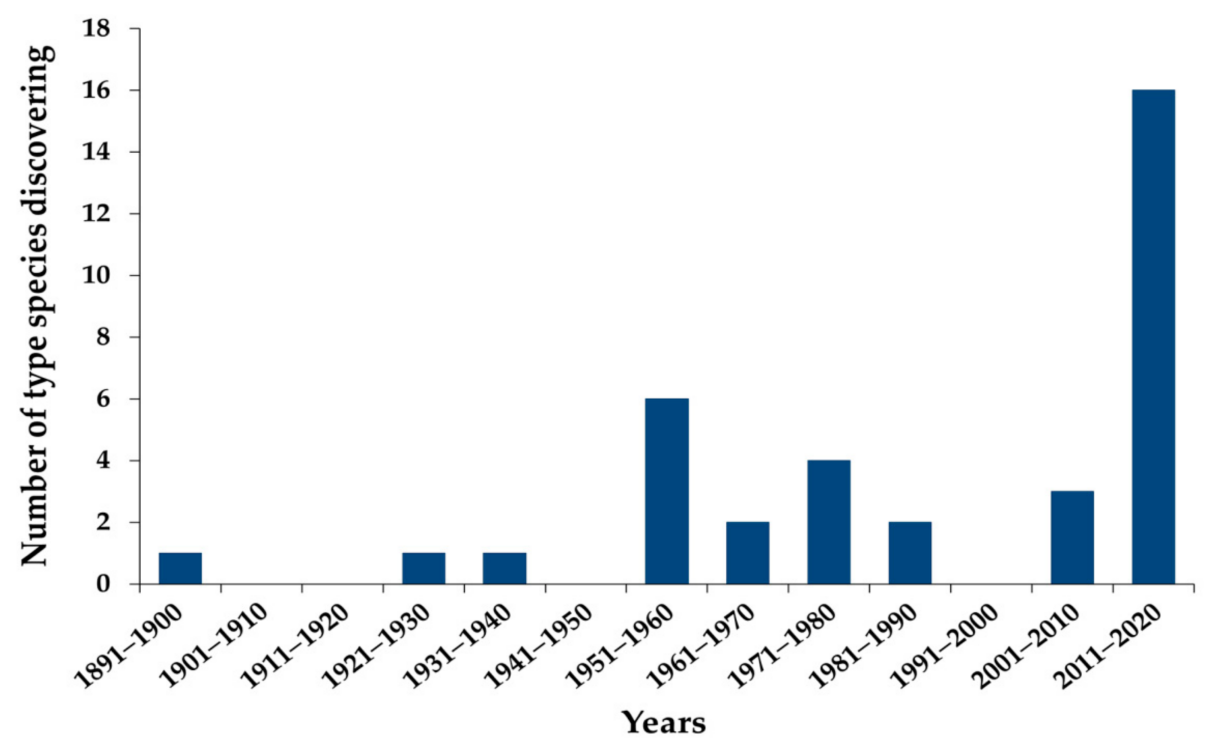

Figure 1. The discovering of Wickerhamomyces type species since 1891 till the present time.

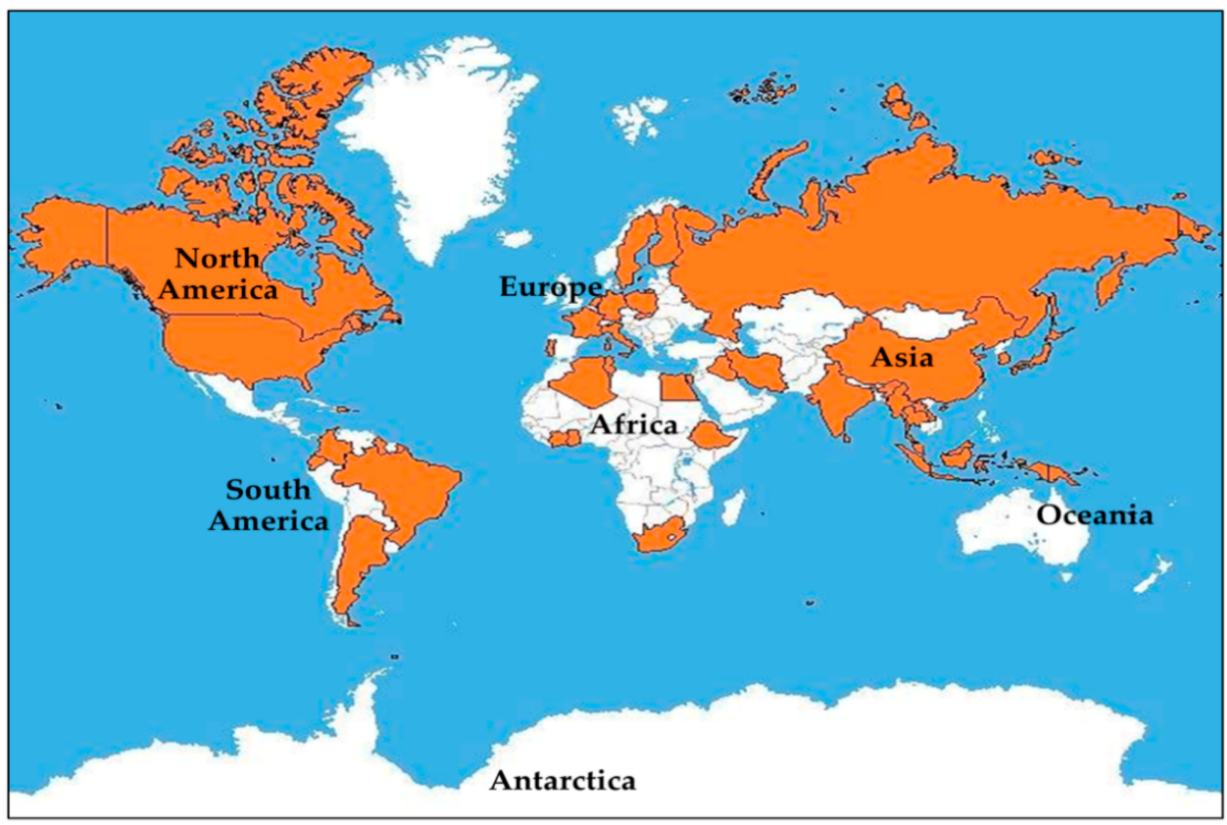

Figure 2. Global distribution of Wickerhamomyces species. The countries where Wickerhamomyces species have been discovered are indicated in orange color. 
Table 1. Global distribution and isolation sources of Wickerhamomyces species.

\begin{tabular}{|c|c|c|c|c|}
\hline No. & Spices & Known Distribution & Isolation Source & Reference \\
\hline 1 & $\begin{array}{l}\text { Wickerhamomyces alni (Phaff, M.W. Mill. } \\
\text { and M. Miranda) Kurtzman, Robnett and } \\
\text { Bas.-Powers }\end{array}$ & Canada & Exudate of Alnus rubra & [12] \\
\hline 2 & $\begin{array}{l}\text { Wickerhamomyces anomalus (E.C. Hansen) } \\
\text { Kurtzman, Robnett and Bas.-Powers }\end{array}$ & $\begin{array}{c}\text { Algeria, Brazil, } \\
\text { China, Colombia, Ethiopia, India, Iraq, } \\
\text { King George Island, Lao, Russia, Slovakia } \\
\text { Sweden and Thailand }\end{array}$ & $\begin{array}{l}\text { Process of beer and wine, phylloplane, } \\
\text { soil, water, coral reefs, Thai traditional } \\
\text { alcoholic starter, mangrove forest, } \\
\text { fermented food, flowers, fruits, } \\
\text { fermented grains, coffee processing, } \\
\text { wastewater treatment plant, Colombian } \\
\text { fermented beans and Brazilian spirit }\end{array}$ & [13-35] \\
\hline 3 & $\begin{array}{l}\text { Wickerhamomyces arborarius S.A. James, } \\
\text { E.J. Carvajal, Barahona, T.C. Harr., C.F. } \\
\text { Lee, C.J. Bond and I.N. Roberts }\end{array}$ & Ecuador & Flower & [36] \\
\hline 4 & $\begin{array}{l}\text { Wickerhamomyces bisporus (O. Beck) } \\
\text { Kurtzman, Robnett and Bas.-Powers }\end{array}$ & Finland, France and USA & $\begin{array}{c}\text { Platypus compositus, phoretic mites on Ips } \\
\text { typographus and bark beetles } \\
\text { (Dendroctonus) }\end{array}$ & [37-39] \\
\hline 5 & $\begin{array}{c}\text { Wickerhamomyces bovis (Uden and Carmo } \\
\text { Souza) Kurtzman, Robnett and } \\
\text { Bas.-Powers }\end{array}$ & Portugal & Caecum of feral cattle (Bos taurus) & {$[40]$} \\
\hline 6 & $\begin{array}{l}\text { Wickerhamomyces canadensis (Wick.) } \\
\text { Kurtzman, Robnett and Bas.-Powers }\end{array}$ & Canada & Beetle frass from Pinus resinosa & {$[41]$} \\
\hline 7 & $\begin{array}{c}\text { Wickerhamomyces chambardii (C. Ramírez } \\
\text { and Boidin) Kurtzman, Robnett and } \\
\text { Bas.-Powers }\end{array}$ & France & Chestnut & [42] \\
\hline 8 & $\begin{array}{l}\text { Wickerhamomyces chaumierensis M. } \\
\text { Groenew., V. Robert and M.T. Sm. }\end{array}$ & Guyana & Surface of flower & [43] \\
\hline 9 & $\begin{array}{l}\text { Wickerhamomyces ciferrii (Lodder) } \\
\text { Kurtzman, Robnett and Bas.-Powers }\end{array}$ & Dominican Republic, USA and Thailand & $\begin{array}{l}\text { Fruit of Dipteryx odorata and male olive } \\
\text { fruit fly (Bactrocera oleae) }\end{array}$ & [44-46] \\
\hline 10 & $\begin{array}{l}\text { Wickerhamomyces edaphicus Limtong, } \\
\text { Yongman., H. Kawas. and Fujiyama }\end{array}$ & India and Thailand & Forest and mangrove soils & {$[4,47]$} \\
\hline 11 & $\begin{array}{c}\text { Wickerhamomyces hampshirensis } \\
\text { (Kurtzman) Kurtzman, Robnett and } \\
\text { Bas.-Powers }\end{array}$ & USA & $\begin{array}{c}\text { Frass of cut and dead of Quercus and } \\
\text { beetle (Xyloterinus politus) }\end{array}$ & {$[48,49]$} \\
\hline 12 & $\begin{array}{l}\text { Wickerhamomyces kurtzmanii A.H. Li, Y.G. } \\
\text { Zhou and Q.M. Wang }\end{array}$ & China & Crater lake water & [6] \\
\hline 13 & $\begin{array}{l}\text { Wickerhamomyces lynferdii (Van der Walt } \\
\text { and Johannsen) Kurtzman, Robnett and } \\
\text { Bas.-Powers }\end{array}$ & South Africa & Soil & [50] \\
\hline 14 & $\begin{array}{l}\text { Wickerhamomyces menglaensis F.L. Hui and } \\
\text { L.N. Huang }\end{array}$ & China & Rotting wood & [51] \\
\hline 15 & $\begin{array}{l}\text { Wickerhamomyces mori F.L. Hui, Liang } \\
\text { Chen, X.Y. Chu, Niu and T. Ke }\end{array}$ & China & $\begin{array}{l}\text { Gut of larvae of wood-boring insect on } \\
\text { trunk of Morus alba }\end{array}$ & {$[52]$} \\
\hline 16 & $\begin{array}{c}\text { Wickerhamomyces mucosus (Wick. and } \\
\text { Kurtzman) Kurtzman, Robnett and } \\
\text { Bas.-Powers }\end{array}$ & USA & Soil & [53] \\
\hline 17 & $\begin{array}{l}\text { Wickerhamomyces myanmarensis (Nagats., } \\
\text { H. Kawas. and T. Seki) J. Kumla, N. } \\
\text { Suwannarach and S. Lumyong }\end{array}$ & Iran and Myanmar & $\begin{array}{l}\text { Palm sugar in rum distiller, and blood } \\
\text { and central venous catheter of patients }\end{array}$ & {$[8,9]$} \\
\hline 18 & Wickerhamomyces ochangensis K.S. Shin & South Korea & Soil of potato field & [11] \\
\hline 19 & $\begin{array}{l}\text { Wickerhamomyces onychis (Yarrow) } \\
\text { Kurtzman, Robnett and Bas.-Powers }\end{array}$ & $\begin{array}{l}\text { Brazil, Ethiopia, Iraq, Malaysia, } \\
\text { Netherlands, Poland and Tunisia }\end{array}$ & $\begin{array}{l}\text { Nail infection of Homo sapiens, fermented } \\
\text { food, cocoa beans, grape and tomato } \\
\text { during spontaneous fermentation, } \\
\text { and soil }\end{array}$ & {$[23,54-59]$} \\
\hline 20 & $\begin{array}{l}\text { Wickerhamomyces orientalis Sipiczki, S. } \\
\text { Nasr, H.D.T. Nguyen and Soudi }\end{array}$ & Iran and Sri Lanka & Fruits and rhizosphere soil & {$[27,60]$} \\
\hline 21 & $\begin{array}{c}\text { Wickerhamomyces patagonicus V. de García, } \\
\text { Brizzio, C.A. Rosa, Libkind and } \\
\text { Van Broock }\end{array}$ & Argentina & $\begin{array}{c}\text { Sap exudate on cut branches of } \\
\text { Nothofagus dombeyi and glacier } \\
\text { meltwater river }\end{array}$ & [61] \\
\hline 22 & $\begin{array}{c}\text { Wickerhamomyces pijperi (Van der Walt \& } \\
\text { Tscheuschner) Kurtzman, Robnett and } \\
\text { Bas.-Powers }\end{array}$ & Egypt, Ghana and South Africa & $\begin{array}{l}\text { Buttermilk, cocoa fermentation and } \\
\text { orange juice }\end{array}$ & [62-64] \\
\hline 23 & $\begin{array}{l}\text { Wickerhamomyces psychrolipolyticus Y. } \\
\text { Shimizu and K. Konno }\end{array}$ & Japan & Soil & [65] \\
\hline 24 & $\begin{array}{l}\text { Wickerhamomyces queroliae C.A. Rosa, P.B. } \\
\text { Morais, Lachance and Pimenta }\end{array}$ & Brazil & $\begin{array}{l}\text { Larva of Anastrepha mucronata from fruit } \\
\text { of Peritassa campestris }\end{array}$ & {$[66]$} \\
\hline 25 & $\begin{array}{c}\text { Wickerhamomyces rabaulensis (Soneda and } \\
\text { S. Uchida) Kurtzman, Robnett and } \\
\text { Bas.-Powers }\end{array}$ & $\begin{array}{l}\text { Ethiopia, Papua New Guinea and } \\
\text { Thailand }\end{array}$ & $\begin{array}{c}\text { Excreta of snail, soils, decaying } \\
\text { agricultural residues, decaying leaves } \\
\text { and tree bark, and } \\
\text { fermented food }\end{array}$ & {$[23,67,68]$} \\
\hline 26 & Wickerhamomyces scolytoplatypi Ninomiya & Japan & $\begin{array}{l}\text { Gallery of beetles (Scolytoplatypus shogun) } \\
\text { in Fagus crenata }\end{array}$ & [69] \\
\hline 27 & $\begin{array}{l}\text { Wickerhamomyces siamensis Kaewwich., } \\
\text { Yongman., H. Kawas. and Limtong }\end{array}$ & Thailand & Phylloplane of Saccharum officinarum & {$[70]$} \\
\hline
\end{tabular}


Table 1. Cont.

\begin{tabular}{|c|c|c|c|c|}
\hline No. & Spices & Known Distribution & Isolation Source & Reference \\
\hline 28 & $\begin{array}{l}\text { Wickerhamomyces silvicola (Wick.) } \\
\text { Kurtzman, Robnett and Bas.-Powers }\end{array}$ & $\begin{array}{l}\text { Germany, South } \\
\text { Korea and USA }\end{array}$ & $\begin{array}{c}\text { Flowers, gum of Prunus serotina and } \\
\text { Prunus wood }\end{array}$ & {$[41,71,72]$} \\
\hline 29 & $\begin{array}{c}\text { Wickerhamomyces spegazzinii Masiulionis } \\
\text { and Pagnocca }\end{array}$ & Argentina & $\begin{array}{l}\text { The fungus garden of an attine ant nest } \\
\text { (Acromyrmex lundii) }\end{array}$ & [73] \\
\hline 30 & $\begin{array}{l}\text { Wickerhamomyces strasburgensis (C. } \\
\text { Ramírez and Boidin) Kurtzman, Robnett } \\
\text { and Bas.-Powers }\end{array}$ & France & On leather tanned by vegetable means & [74] \\
\hline 31 & $\begin{array}{c}\text { Wickerhamomyces subpelliculosus } \\
\text { (Kurtzman) Kurtzman, Robnett and } \\
\text { Bas.-Powers }\end{array}$ & Egypt and USA & $\begin{array}{l}\text { Fermenting cucumber brines, gut of } \\
\text { honey bee and molasses }\end{array}$ & {$[75,76]$} \\
\hline 32 & $\begin{array}{c}\text { Wickerhamomyces sydowiorum (D.B. Scott } \\
\text { and Van der Walt) Kurtzman, Robnett } \\
\text { and Bas.-Powers }\end{array}$ & $\begin{array}{l}\text { Brazil, Ivory Coast, South Africa } \\
\text { and Thailand }\end{array}$ & $\begin{array}{l}\text { Frass of Sinoxylon ruficorne in dead } \\
\text { Combretum apiculatum, decayed plant leaf, } \\
\text { fermented cocoa, honey, sand and water }\end{array}$ & {$[59,77-80]$} \\
\hline 33 & $\begin{array}{c}\text { Wickerhamomyces sylviae Moschetti } \\
\text { and J.P. Samp. }\end{array}$ & Italy & $\begin{array}{l}\text { Cloaca of migratory birds } \\
\text { (Sylvia communis) }\end{array}$ & [81] \\
\hline 34 & $\begin{array}{c}\text { Wickerhamomyces tratensis Nakase, } \\
\text { Jindam., Am-In, Ninomiya and H. } \\
\text { Kawas. }\end{array}$ & Thailand & $\begin{array}{l}\text { Flower of mangrove apple } \\
\quad \text { (Sonneratia caseolaris) }\end{array}$ & {$[82]$} \\
\hline 35 & $\begin{array}{l}\text { Wickerhamomyces xylosicus Limtong, } \\
\text { Nitiyon, Kaewwich., Jindam., Am-In } \\
\text { and Yongman }\end{array}$ & Thailand & Soil & [5] \\
\hline 36 & $\begin{array}{l}\text { Wickerhamomyces xylosivorus R. Kobay., A. } \\
\text { Kanti and H. Kawas. }\end{array}$ & Indonesia & Decayed wood & [4] \\
\hline
\end{tabular}

\section{Materials and Methods}

\subsection{Yeast Strain}

Five yeasts strains (SDBR-CMU-S2-02, SDBR-CMU-S2-06, SDBR-CMU-S2-14, SDBRCMU-S2-17 and CMU-S3-15) isolated from soils of Assam tea (C. sinensis var. assamica) plantations in Thep Sadej, Doi Saket District, Chiang Mai Province and Sri Na Pan, Muang District, Nan Province, northern Thailand [16] were selected for this present study. All strains were deposited in the culture collection of the Sustainable Development of Biological Resources, Faculty of Science, Chiang Mai University (SDBR-CMU), Chiang Mai Province and Thailand Bioresource Research Center (TBRC), Pathum Thani Province, Thailand.

\subsection{Yeast Identification}

\subsubsection{Morphological Study}

The morphological characteristics of yeast strains were determined according to established methods by Kurtzman et al. [2], Yarrow [3] and Limtong et al. [10]. Colony characters were observed on yeast extract-malt extract agar (YMA) after two days of incubation in darkness at $30^{\circ} \mathrm{C}$. Ascospore formation was investigated on $\mathrm{YMA}, 5 \%$ malt extract agar (MEA), potato dextrose agar (PDA) and V8 agar after incubation at $25^{\circ} \mathrm{C}$ in the dark for four weeks. Micromorphological characteristics were examined under a light microscope (Nikon Eclipse Ni U, Tokyo, Japan). Size data of the anatomical structure (e.g., cells, pseudohyphae, asci and ascospores) were based on at least 50 measurements of each structure using the Tarosoft (R) Image Frame Work program.

\subsubsection{Biochemical and Physiological Studies}

Biochemical and physiological characterizations of yeast strains was followed the previous studies [2,3,115]. Fermentation of carbohydrates including glucose, galactose, maltose, sucrose, trehalose, melibiose, lactose, raffinose, and xylose were performed. Additionally, assimilation tests for carbon (D-glucose, D-galactose, L-sorbose, N-acetyl glucosamine, D-ribose, D-xylose, L-arabinose, D-arabinose, rhamnose, sucrose, maltose, $\alpha, \alpha$-trehalose, $\alpha$-methyl-D-glucoside, cellobiose, salicin, melibiose, lactose, raffinose, melezitose, inulin, soluble starch, glycerol, erythritol, ribitol, D-glucitol, D-mannitol, galactitol, myo-inositol, D-glucono-1,5-lactone, 2-ketogluconic acid, 5-ketogluconic acid, D-gluconate, D-glucuronate, D-galacturonic acid, DL-lactate, succinate, citrate, methanol, ethanol, and xylitol) and nitrogen compounds (ammonium sulfate, potassium nitrate, sodium nitrite, 
ethylamine hydrochloride, L-lysine, cadaverine, and creatine) were determined. Moreover, the effects of temperature on growth were examined by cultivation on YMA at temperature ranging from $15-45^{\circ} \mathrm{C}$ and diazonium blue $\mathrm{B}$ reactions were tested [116].

\subsubsection{Molecular Study}

Each yeast strain was grown in $5 \mathrm{~mL}$ of yeast extract-malt extract broth in $18 \times 180 \mathrm{~mm}$ test tubes with shaking at $150 \mathrm{rpm}$ on an orbital shaker in the dark for two days. Yeast cells were harvested by centrifugation at 11,000 rpm and washed three times with sterile distilled water. Genomic DNA was extracted from yeast cells using DNA Extraction Mini Kit (FAVORGEN, Taiwan) following the manufacturer's protocol. The ITS region and D1/D2 domains of LSU gene were amplified by polymerase chain reactions (PCR) using ITS1/ITS4 primers [117] and NL1/NL4 primers [118], respectively. The amplification of both D1/D2 domains and ITS region process consisted of an initial denaturation at $95^{\circ} \mathrm{C}$ for $5 \mathrm{~min}$, followed by 35 cycles of denaturation at $95^{\circ} \mathrm{C}$ for $30 \mathrm{~s}$, annealing at $52^{\circ} \mathrm{C}$ for $45 \mathrm{~s}$, an extension at $72{ }^{\circ} \mathrm{C}$ for $1 \mathrm{~min}$ and $72{ }^{\circ} \mathrm{C}$ for $10 \mathrm{~min}$ on a peqSTAR thermal cycler (PEQLAB Ltd., UK). PCR products were checked and purified by a PCR clean up Gel Extraction NucleoSpin ${ }^{\circledR}$ Gel and PCR Clean-up Kit (Macherey-Nagel, Germany). Final PCR products were sent to 1st Base Company Co., Ltd., (Kembangan, Malaysia) for sequencing. The obtained sequences were used to query GenBank via BLAST (http:/ / blast.ddbj.nig.ac.jp/top-e.html, accessed on 25 August 2021).

Phylogenetic analysis was carried out based on the combined dataset of ITS and D1/D2 domains of LSU sequences. Sequences from this study along with those obtained from previous studies and the GenBank database were selected and provided in Table 2. Multiple sequence alignment was performed using MUSCLE [119]. A combination of D1/D2 domains of LSU and ITS alignment was deposited in TreeBASE under the study ID number 28785. A phylogenetic tree was constructed under maximum likelihood (ML) and Bayesian inference (BI) methods. The ML analysis was carried out using RAxML-HPC2 on XSEDE (8.2.10) in CIPRES Science Gateway V. 3.3 [120] using GTRCAT model with 25 categories and 1000 bootstrap (BS) replications. The optimum nucleotide substitution model was obtained using jModeltest v.2.3 [121] under the Akaike information criterion (AIC) method. The BI analysis was performed using MrBayes 3.2.6 software for Windows [122]. The selected optimal model of each gene is similar as GTR + I + G model. Six simultaneous Markov chains were run with one million generations and starting from random trees and keeping one tree every 100th generation until the average standard deviation of split frequencies was below 0.01 . The value of burn-in was set to discard $25 \%$ of trees when calculating the posterior probabilities. Bayesian posterior probabilities (PP) were obtained from the $50 \%$ majority rule consensus of the trees kept. The tree topologies were visualized in FigTree v1.4.0 [123].

Table 2. DNA sequences used in the molecular phylogenetic analysis. Type strains indicated by "T".

\begin{tabular}{|c|c|c|c|c|}
\hline \multirow{2}{*}{ Yeast Species } & \multirow{2}{*}{ Strain } & \multicolumn{2}{|c|}{ GenBank Acession Number } & \multirow{2}{*}{ Reference } \\
\hline & & ITS & D1/D2 & \\
\hline \multirow{2}{*}{ Wickerhamomyces alni } & NRRL Y-11625T & - & EF550294 & [1] \\
\hline & CBS 6986 & NR154966 & KY110065 & [124] \\
\hline \multirow{2}{*}{ Wickerhamomyces anomalus } & NRRL Y-366 ${ }^{\mathrm{T}}$ & - & EF550341 & [1] \\
\hline & H1Wh & JQ857021 & JQ856997 & [17] \\
\hline Wickerhamomyces arborarius & $\mathrm{Bq} 164^{\mathrm{T}}$ & NR_55000 & FN908198 & {$[36]$} \\
\hline Wickerhamomyces bisporus & NRRL Y-1482 & - & EF550296 & {$[1]$} \\
\hline \multirow{2}{*}{ Wickerhamomyces bovis } & NRRL YB- $4184^{\mathrm{T}}$ & - & EF550298 & [1] \\
\hline & CBS 2616 & NR154968 & KY110109 & [124] \\
\hline \multirow{2}{*}{ Wickerhamomyces canadensis } & NRRL Y-1888 & - & EF550300 & [1] \\
\hline & GoToruMP327 & EF093299 & EF016107 & [125] \\
\hline
\end{tabular}


Table 2. Cont.

\begin{tabular}{|c|c|c|c|c|}
\hline \multirow{2}{*}{ Yeast Species } & \multirow{2}{*}{ Strain } & \multicolumn{2}{|c|}{ GenBank Acession Number } & \multirow{2}{*}{ Reference } \\
\hline & & ITS & D1/D2 & \\
\hline \multirow{2}{*}{ Wickerhamomyces chambardii } & NRRL Y-2378 & - & EF550344 & {$[1]$} \\
\hline & CBS 1900 & NR154969 & KY110114 & [124] \\
\hline Wickerhamomyces chaumierensis & CBS $8565^{\mathrm{T}}$ & HM156503 & HM156533 & [43] \\
\hline \multirow{2}{*}{ Wickerhamomyces ciferrii } & NRRL Y-1031 & - & EF550339 & [1] \\
\hline & UCDFST 83-22 & MH153583 & MH130275 & [126] \\
\hline \multirow{2}{*}{ Wickerhamomyces edaphicus } & $\mathrm{S}-29^{\mathrm{T}}$ & AB436771 & AB436763 & {$[10]$} \\
\hline & CBS 10408 & KY105904 & KY110120 & [124] \\
\hline Wickerhamomyces hampshirensis & NRRL YB-4128 & - & EF550334 & [1] \\
\hline Wickerhamomyces kurtzmanii & TF5-16-2 ${ }^{\mathrm{T}}$ & MK573939 & MK573939 & [6] \\
\hline \multirow{3}{*}{ Wickerhamomyces lannaensis } & SDBR-CMU-S3-15 ${ }^{\mathrm{T}}$ & OK135750 & MT639220 & This study, [16] \\
\hline & SDBR-CMU-S2-02 & OK135752 & MT623569 & This study, [16] \\
\hline & SDBR-CMU-S2-06 & OK135753 & MT613722 & This study, [16] \\
\hline \multirow{2}{*}{ Wickerhamomyces lynferdii } & NRRL Y-7723 & EF550342 & EF550342 & [1] \\
\hline & BCRC 22676 & NR111798 & - & [127] \\
\hline Wickerhamomyces menglaensis & NYNU $1673^{\mathrm{T}}$ & KY213818 & KY213812 & [51] \\
\hline \multirow{2}{*}{ Wickerhamomyces mori } & NYNU $1216^{\mathrm{T}}$ & JX204288 & JX204287 & {$[52]$} \\
\hline & NYNU 1204 & JX292100 & JX292099 & [52] \\
\hline \multirow{2}{*}{ Wickerhamomyces mucosus } & NRRL YB-1344 & - & EF550337 & {$[1]$} \\
\hline & CBS 6341 & Z93877 & KY110124 & [124] \\
\hline \multirow{2}{*}{ Wickerhamomyces myanmarensis } & CBS $9786^{\mathrm{T}}$ & - & AB126678 & [9] \\
\hline & SU-263 & MH236221 & MH236219 & {$[8]$} \\
\hline \multirow{2}{*}{ Wickerhamomyces nanensis } & SDBR-CMU-S2-17 ${ }^{\mathrm{T}}$ & OK143510 & MT613875 & This study, [16] \\
\hline & SDBR-CMU-S2-14 & OK143511 & MT623571 & This study, [16] \\
\hline \multirow{2}{*}{ Wickerhamomyces ochangensis } & $\mathrm{N} 7 \mathrm{a}-\mathrm{Y} 2^{\mathrm{T}}$ & NR154971 & HM485464 & {$[11]$} \\
\hline & CBS 11843 & KY105909 & - & [124] \\
\hline \multirow{2}{*}{ Wickerhamomyces onychis } & NRRL Y-7123 ${ }^{\mathrm{T}}$ & - & EF550279 & [1] \\
\hline & CBS 5587 & KY105910 & KY110125 & [124] \\
\hline \multirow{2}{*}{ Wickerhamomyces orientalis } & $\mathrm{KH}-\mathrm{D} 1^{\mathrm{T}}$ & KF938677 & KF938676 & {$[60]$} \\
\hline & $12-101$ & KU253704 & KU253703 & [60] \\
\hline \multirow{2}{*}{ Wickerhamomyces patagonicus } & CRUB $1724^{\mathrm{T}}$ & FJ793131 & FJ666399 & {$[61]$} \\
\hline & CBS 11398 & NG057185 & KY110126 & [124] \\
\hline \multirow{2}{*}{ Wickerhamomyces pijperi } & NRRL YB-4309T & - & EF550335 & [1] \\
\hline & CBS 2887 & HM156502 & KY110127 & [124] \\
\hline \multirow{2}{*}{ Wickerhamomyces psychrolipolyticus } & $Y 08-202-2^{\mathrm{T}}$ & - & LC333101 & [65] \\
\hline & Y08-202-2 & - & LC333102 & {$[65]$} \\
\hline Wickerhamomyces queroliae & UFMG-T05-200 & EU580140 & EU580140 & {$[66]$} \\
\hline \multirow{2}{*}{ Wickerhamomyces rabaulensis } & NRRL Y-7945 & - & EF550303 & {$[1]$} \\
\hline & CBS 6797 & KY105914 & KY110128 & [124] \\
\hline \multirow{2}{*}{ Wickerhamomyces scolytoplatypi } & NBRC $11029^{\mathrm{T}}$ & - & AB534166 & {$[69]$} \\
\hline & CBS 12186 & KY105915 & KY110130 & [124] \\
\hline
\end{tabular}


Table 2. Cont.

\begin{tabular}{|c|c|c|c|c|}
\hline \multirow{2}{*}{ Yeast Species } & \multirow{2}{*}{ Strain } & \multicolumn{2}{|c|}{ GenBank Acession Number } & \multirow{2}{*}{ Reference } \\
\hline & & ITS & D1/D2 & \\
\hline \multirow{2}{*}{ Wickerhamomyces siamensis } & DMKU-RK359T & NR111029 & AB714248 & [70] \\
\hline & CBS 12570 & KY105916 & KY110131 & [124] \\
\hline \multirow{2}{*}{ Wickerhamomyces silvicola } & NRRL Y-1678 & - & EF550302 & [1] \\
\hline & GLMC 1708 & MT156140 & MT156324 & [71] \\
\hline Wickerhamomyces spegazzinii & JLU025 & KJ832072 & KJ832071 & [73] \\
\hline Wickerhamomyces strasburgensis & NRRL Y-2383 & - & EF550333 & [1] \\
\hline Wickerhamomyces subpelliculosus & NRRL Y-1683 ${ }^{T}$ & NR111336 & EF550340 & {$[1,127]$} \\
\hline \multirow{2}{*}{ Wickerhamomyces sydowiorum } & NRRL Y-7130 & NR138219 & EF550343 & {$[1,36]$} \\
\hline & NRRL Y-10996 & FR690145 & FR690073 & [36] \\
\hline \multirow{2}{*}{ Wickerhamomyces sylviae } & PYCC6345 & - & KF240728 & [81] \\
\hline & U92A1 & - & KF240729 & [81] \\
\hline \multirow{2}{*}{ Wickerhamomyces tratensis } & NBRC $107799^{\mathrm{T}}$ & AB607029 & AB607028 & [82] \\
\hline & CBS 12176 & KY105935 & KY110150 & [124] \\
\hline \multirow{2}{*}{ Wickerhamomyces xylosica } & CBS $12320^{\mathrm{T}}$ & NR160310 & AB557867 & [5] \\
\hline & NT31 & AB704715 & NG064304 & [5] \\
\hline \multirow{2}{*}{ Wickerhamomyces xylosivorus } & NBRC $111553^{\mathrm{T}}$ & NR155013 & LC202858 & [4] \\
\hline & $14 Y 125$ & - & NG057186 & [4] \\
\hline Saccharomyces cerevisiae & NRRL Y-12632 & AY046146 & JQ689017 & [128] \\
\hline Spathaspora allomyrinae & CBS $13924^{\mathrm{T}}$ & КР054268 & KP054267 & [129] \\
\hline
\end{tabular}

Note: sepecies obtained in this study are in bold.

\section{Results}

\subsection{Phylogenetic Results}

The sequences of five yeast strains were deposited in the GenBank database (Table 2). The alignment of a combination of ITS and D1/D2 domains of the LSU genes contained 1544 characters including gaps (ITS: $1-823$ and D1/D2 domains of LSU: $824-1544)$. RAxML analysis of the combined dataset yielded a best scoring tree with a final ML optimization likelihood value of $-12,120.4323$. The matrix contained 776 distinct alignment patterns with $42.33 \%$ undetermined characters or gaps. Estimated base frequencies were recorded as follows: $\mathrm{A}=0.2730, \mathrm{C}=0.1821, \mathrm{G}=0.2603, \mathrm{~T}=0.2844$; substitution rates $\mathrm{AC}=1.0574$, $\mathrm{AG}=2.0209, \mathrm{AT}=1.4684, \mathrm{CG}=0.6712, \mathrm{CT}=4.4165, \mathrm{GT}=1.0000$. The gamma distribution shape parameter alpha was equal to 0.2698 and the Tree-Length was equal to 4.4075 . In addition, the final average standard deviation of the split frequencies at the end of the total MCMC generations was calculated as 0.00638 through BI analysis. Phylograms of the ML and BI analyses were similar in terms of topology (data not shown). Therefore, the phylogram obtained from the ML analysis was selected and presented for this study. The phylogram was comprised of 67 sequences of Wickerhamomyces strains (including 37 type strains obtained from either previous studies or the present study) and two sequences (Saccharomyces cerevisiae NRRL 12632 and Spathaspora allomyrinae CBS 13924) of the outgroup (Figure 3). Our phylogenetic analysis separated Wickerhamomyces by different species based on different topologies. Our analysis confirmed that $W$. myanmarensis (previously known as $P$. myanmarensis) belonged to the genus Wickerhamomyces according to the phylogenetic results of Arastehfar et al. [8] and Shimizu et al. [65]. Moreover, a phylogram clearly separated our yeast strains into two monophyletic clades with high support values $(B S=100 \%$ and $\mathrm{PP}=1.0$ ). The results indicated that our two yeast strains, SDBR-CMU-S2-17 and 
SDBR-CMU-S2-14 (introduced as W. nanensis), were clearly distinguished from the previously known species of Wickerhamomyces. Moreover, three yeast strains in this study, SDBR-CMU-S2-02, SDBR-CMU-S2-15, and CMU-S3-06 (described here as W. lannaensis) formed a sister clade to $W$. ochangensis with high support $(B S=100 \%$ and $P P=1.0)$.

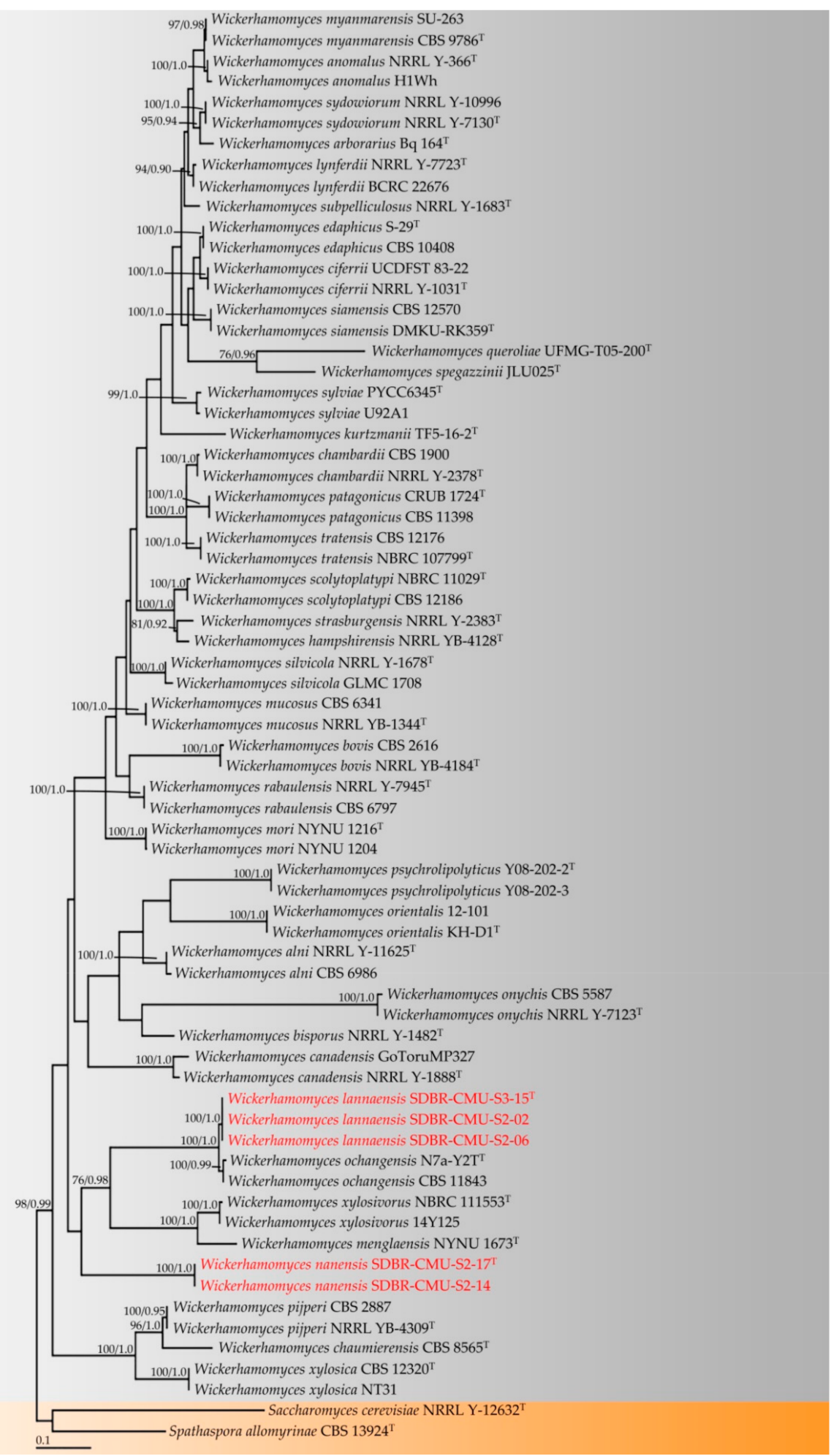

Figure 3. Phylogram derived from maximum likelihood analysis of 69 sequences of the combined ITS and D1/D2 sequences. Saccharomyces cerevisiae NRRL 12632 and Spathaspora allomyrinae CBS 13924 were used as the outgroup. The numbers above branches represent bootstrap percentages (left) and Bayesian posterior probabilities (right). Bootstrap values $\geq 75 \%$ and Bayesian posterior probabilities $\geq 0.90$ are shown. Sequences obtained in this study are in red. Superscription " $\mathrm{T}$ " means the type strains. 


\subsection{Taxonomic Description of New Species}

3.2.1. Wickerhamomyces lannaensis S. Nundaeng, J. Kumla, N. Suwannarach and S. Lumyong, sp. nov. (Figure 4)

Mycobank No.: 841356

Etymology: "lannaensis" refers to Lanna kingdom the historic name of northern Thailand, the collection locality of the type strain of the species.

Holotype: Thailand, Chiang Mai Province, Thep Sadej, Doi Saket District, in soil from Assam tea (C. sinensis var. assamica) plantation, May 2017, J. Kumla and N. Suwannarach, (holotype SDBR-CMU-S3-15 ${ }^{\mathrm{T}}$, culture ex-type TBRC 15533)
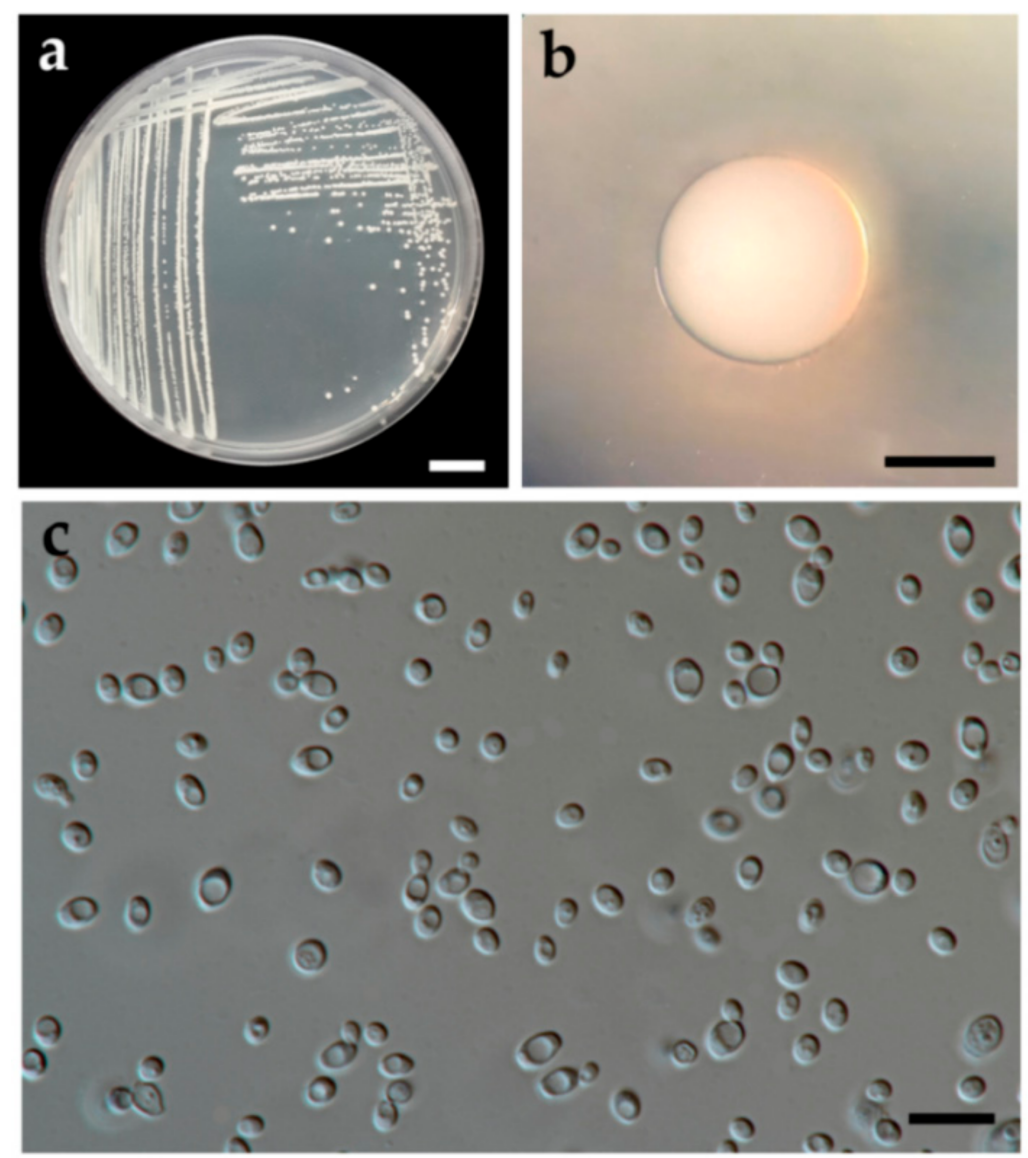

Figure 4. Wickerhamomyces lannaensis (holotype SDBR-CMU-S3-15). Culture (a), single colony (b) and budding cells (c) on YMA after two days at $30^{\circ} \mathrm{C}$. Scale bar a and $\mathrm{b}=10 \mathrm{~cm}, \mathrm{c}=10 \mu \mathrm{m}$.

Description: The streak culture on YMA after two days at $30{ }^{\circ} \mathrm{C}$ is circular from (1-2 $\mathrm{mm}$ in diameter), white to cream color, smooth surface, dull-shining, entire margin, and raised elevation. After growth on YMA at $30^{\circ} \mathrm{C}$ for two days, the cells are spheroidal to short ovoidal (3.6-3.8 $\times 2.4-2.6 \mu \mathrm{m})$, occur singly or in budding pairs. Pseudohyphae and true hyphae were absent. Ascospores were not obtained for individual strains and strain pairs on YMA, $5 \%$ MEA, PDA and V8 agar after incubation at $30^{\circ} \mathrm{C}$ for one month. Urea hydrolysis and diazonium blue B reactions are negative. Fermentation tests, glucose is delayed positive, but galactose, maltose, sucrose, trehalose, melibiose, lactose, raffinose, and xylose are negative. D-glucose, D-xylose, rhamnose, cellobiose, salicin, inulin (weak), glycerol, D-glucitol, D-mannitol, D-glucono-1,5-lactone, D-gluconate, DL-lactate (weak), succinate, and ethanol are assimilated. No growth was observed in L-sorbose, $\mathrm{N}$-acetyl glucosamine, D-ribose, L-arabinose, D-arabinose, sucrose, maltose, $\alpha, \alpha$-trehalose, $\alpha$-methyl-D-glucoside, melibiose, lactose, raffinose, melezitose, soluble starch, erythritol, ribitol, galactitol, myo-inositol, 2-ketogluconic acid, 5-ketogluconic acid, D-glucuronate, D-galacturonic acid, citrate, methanol, and xylitol. For the assimilation of nitrogen com- 
pounds, growth on ammonium sulfate, potassium nitrate, sodium nitrite, ethylamine $\mathrm{HCl}$, cadaverine, and creatine (weak) are positive and on L-lysine is latent positive.

Growth in the vitamin-free medium is weak positive. Growth was observed at $15^{\circ} \mathrm{C}$ and $30{ }^{\circ} \mathrm{C}$, but not at $35,37,40,42$ and $45^{\circ} \mathrm{C}$. Growth in the presence of $50 \%$ glucose is positive, but growth in the presence of $0.01 \%$ cycloheximide, $0.1 \%$ cycloheximide, $60 \%$ glucose, $10 \% \mathrm{NaCl}$ with $5 \%$ glucose and $15 \% \mathrm{NaCl}$ with $5 \%$ glucose are negative. Acid formation is negative.

Additional strains examined: Thailand, Nan Province, Muang District, Sri Na Pan, in soil from Assam tea (C. sinensis var. assamica) plantation, September 2016, J. Kumla and N. Suwannarach, SDBR-CMU-S2-02, SDBR-CMU-S2-06.

GenBank accession numbers: holotype SDBR-CMU-S3-15 (D1/D2: MT639220, ITS: OK135750); additional strains SDBR-CMU-S2-02 (D1/D2: MT623569, ITS: OK135752) and SDBR-CMU-S2-06 (D1/D2: MT613722, ITS: OK135753).

Note: Based on phylogenetic analyses, $W$. lannaensis formed a monophyletic clade in a well-supported clade and was found to be closely related to W. ochangensis (Figure 3). Wickerhamomyces lannaensis can be distinguished from $W$. ochangensis by its ability to assimilate inulin and creatine and its growth in $50 \%$ glucose medium [11]. Additionally, $W$. ochangensis was able to grow at a temperature of $37^{\circ} \mathrm{C}$, while $W$. lannaensis could not grow at $37^{\circ} \mathrm{C}$ [11].

3.2.2. Wickerhamomyces nanensis J. Kumla, S. Nundaeng, N. Suwannarach and S. Lumyong, sp. nov. (Figure 5)

Mycobank No.: 841357

Etymology: "nanensis" refers to Nan Province of Thailand, the collection locality of the type strain of the species.

Holotype: Thailand, Nan Province, Muang District, Sri Na Pan, in soil from Assam tea (C. sinensis var. assamica) plantation, September 2016, J. Kumla, N. Suwannarach and S. Khuna, (holotype SDBR-CMU-S2-17 ${ }^{\mathrm{T}}$, culture ex-type TBRC 15534)

Description: The streak culture on YMA after two days at $30{ }^{\circ} \mathrm{C}$ is circular from (1-2 mm in diameter), white to cream color, smooth surface, dull-shining, entire margin, and raised elevation. After growth on YMA at $30^{\circ} \mathrm{C}$ for two days, the cells are spheroidal to short ovoidal $(3.8-4.0 \times 2.4-2.5 \mu \mathrm{m})$, occur singly or in budding pairs. Pseudohyphae $(4.8-6.9 \times 2.2-2.9 \mu \mathrm{m})$ were produced in Dalmau plate culture on 5\% MEA and PDA after 7 days at $25{ }^{\circ} \mathrm{C}$, but true hyphae are not obtained. Ascospores were not observed for individual strains and strain pairs on YMA, 5\% MEA, PDA and V8 agar after incubation at $30^{\circ} \mathrm{C}$ for one month. Urea hydrolysis and diazonium blue $\mathrm{B}$ reactions are negative. Fermentation test, glucose is delayed positive, but galactose, maltose, sucrose, trehalose, melibiose, lactose, raffinose, and xylose are not positive. D-glucose, D-galactose, cellobiose, salicin, glycerol, D-mannitol, D-glucono-1,5-lactone, DL-lactate (weak), succinate, citrate, and ethanol are assimilated. No growth was observed in L-sorbose, $\mathrm{N}$-acetyl glucosamine, D-ribose, D-xylose, L-arabinose, D-arabinose, rhamnose, sucrose, maltose, $\alpha, \alpha$-trehalose, $\alpha$-methyl-D-glucoside, melibiose, lactose, raffinose, melezitose, inulin, soluble starch, erythritol, ribitol, D-glucitol, galactitol, myo-inositol, 2-ketogluconic acid, 5-ketogluconic acid, D-gluconate, D-glucuronate, D-galacturonic acid, methanol, and xylitol. For the assimilation of nitrogen compounds, growth on ammonium sulfate, potassium nitrate (weak), sodium nitrite (weak), ethylamine $\mathrm{HCl}$, l-lysine, and creatine (slow) are positive, but cadaverine is not. Growth in the vitamin-free medium is weak. Growth was observed at $15{ }^{\circ} \mathrm{C}$ and $30{ }^{\circ} \mathrm{C}$, but not at $35,37,40,42$ and $45^{\circ} \mathrm{C}$. Growth in the presence of $50 \%$ glucose and acid formation are positive, but growth in the presence of $0.01 \%$ cycloheximide, $0.1 \%$ cycloheximide, $60 \%$ glucose, $10 \% \mathrm{NaCl}$ with $5 \%$ glucose, and $15 \% \mathrm{NaCl}$ with $5 \%$ glucose are negative.

Additional strain examined: Thailand, Nan Province, Muang District, Sri Na Pan, in soil from Assam tea (C. sinensis var. assamica) plantation, September 2016, J. Kumla and N. Suwannarach, SDBR-CMU-S2-14. 
GenBank accession numbers: holotype SDBR-CMU-S2-17 (D1/D2: MT613875, ITS: OK143510); additional strain SDBR-CMU-S2-14 (D1/D2: MT623569, ITS: OK143511).

Note: Several morphological and biochemical characteristics of $W$. nanensis were similar to $W$. chambardii. However, $W$. chambardii differed from $W$. nanensis by its ascospore formation and could not assimilate D-mannitol [2]. Phylogenetic analyses clearly separated $W$. nanensis and W. chambardii as different species. Moreover, W. nanensis formed a monophyletic clade in a well-supported clade and was separated from other Wickerhamomyces species (Figure 3).
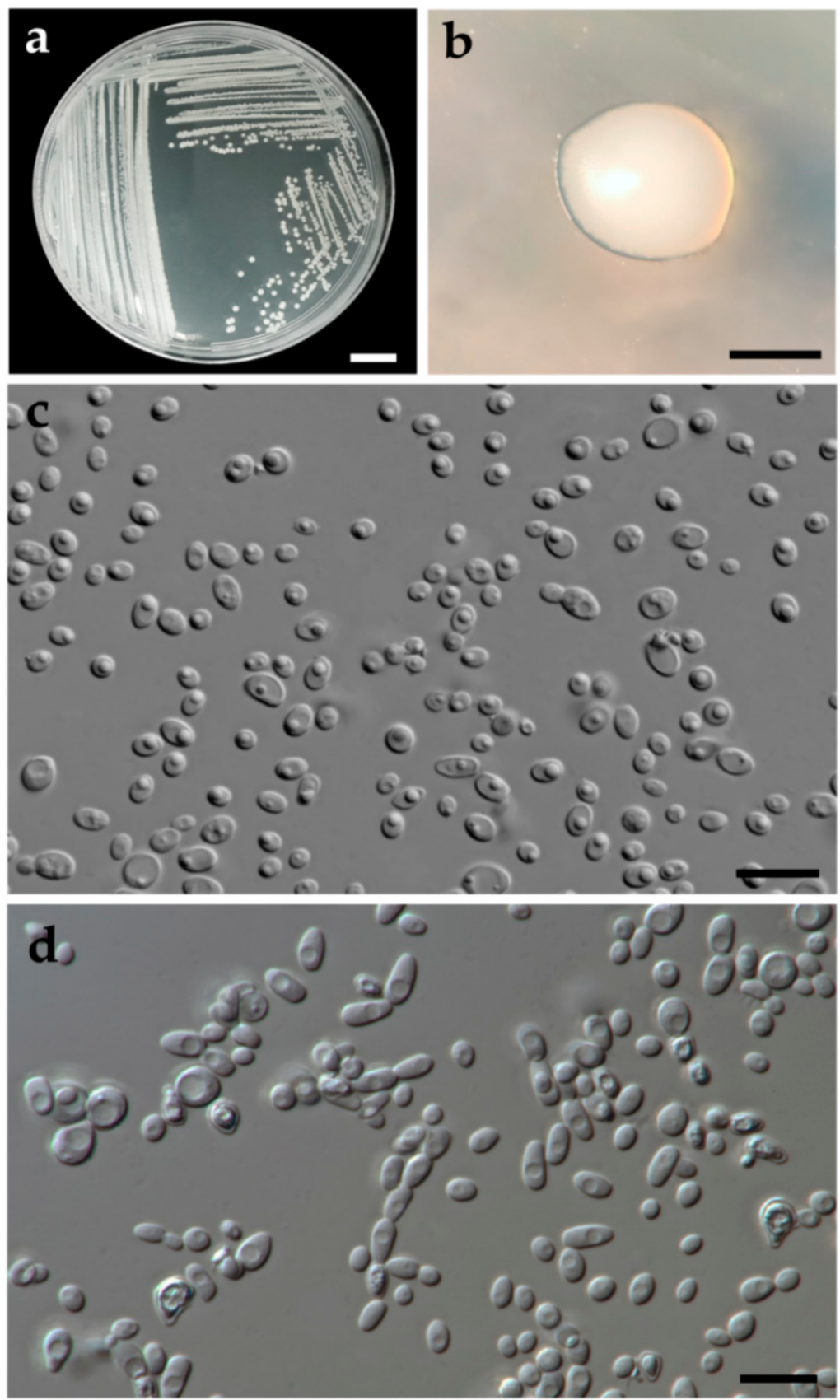

Figure 5. Wickerhamomyces nanensis (holotype SDBR-CMU-S3-15). Culture (a), single colony (b) and budding cells (c) on YMA after two days at $30^{\circ} \mathrm{C}$. Pseudohypahae (d) on $5 \%$ MAE agar after 7 days at $25^{\circ} \mathrm{C}$. Scale bar a and $\mathrm{b}=10 \mathrm{~cm}, \mathrm{c}$ and $\mathrm{d}=10 \mu \mathrm{m}$. 


\subsection{New Combination}

Wickerhamomyces myanmarensis (Nagats., H. Kawas. and T. Seki) J. Kumla, N. Suwannarach and S. Lumyong, comb. nov.

Mycobank No.: 841356

Basionym: Pichia myanmarensis Nagats., H. Kawas. and T. Seki, Int. J. Syst. Evol. Microbiol. 55: 1381, 2005.

Note: The combined ITS and D1/D2 phylogenetic analyses indicated that the type species, P. myanmarensis, belongs to the genus Wickerhamomyces and has a close phylogenetic relationship with $W$. anomalus (Figure 3). Accordingly, the phylogenetic results of Arastehfar et al. [8] and Shimizu et al. [65] found that P. myanmarensis was placed within the genus Wickerhamomyces.

\subsection{Key to Species of Wickerhamomyces}

A key to the identification of the Wickerhamomyces species introduced in the present study was derived from the key described by Kurtzman et al. [2]. Key characteristics are shown in Table 3.

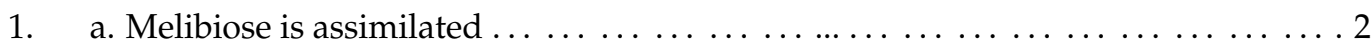

b. Melibiose is not assimilated $\ldots \ldots \ldots \ldots \ldots \ldots \ldots \ldots \ldots \ldots \ldots \ldots$

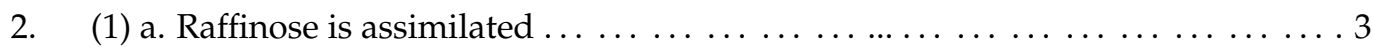

b. Raffinose is not assimilated ............................ kurtzmanii

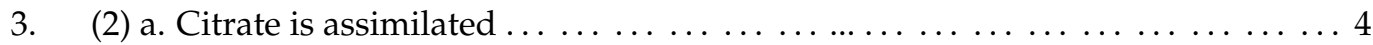

b. Citrate is not assimilated $\ldots \ldots \ldots \ldots \ldots \ldots \ldots \ldots \ldots \ldots \ldots \ldots \ldots \ldots \ldots$ orientalis

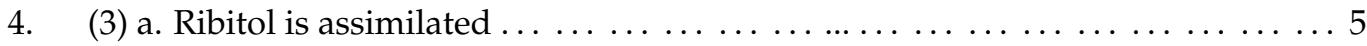

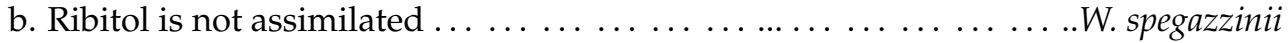

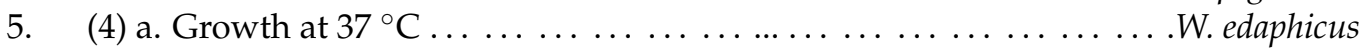

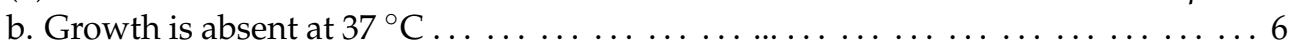

6. (5) a. Ascospores observed on $5 \%$ MEA . . . . . . . . . . . . . . W. sydowiorum

b. Ascospores not observed on $5 \%$ MEA $\ldots \ldots \ldots \ldots \ldots \ldots \ldots \ldots$. arborarius

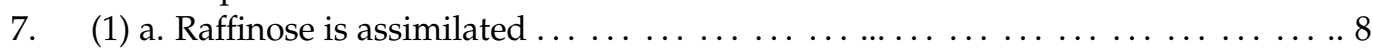

b. Raffinose is not assimilated $\ldots \ldots \ldots \ldots \ldots \ldots \ldots \ldots \ldots$

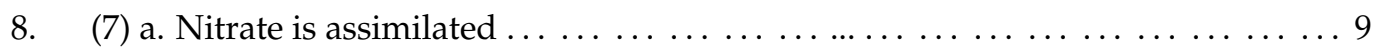

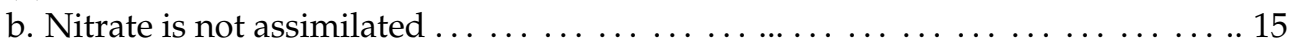

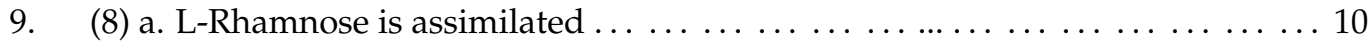

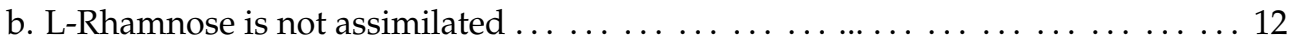

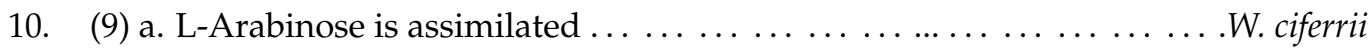

b. L-Arabinose is not assimilated $\ldots \ldots \ldots \ldots \ldots \ldots \ldots \ldots \ldots \ldots \ldots \ldots \ldots$

11. (10) a. Sucrose is assimilated ..................... psychrolipolyticus

b. Sucrose is not assimilated $\ldots \ldots \ldots \ldots \ldots \ldots \ldots \ldots \ldots \ldots . \ldots \ldots$ xylosivorus

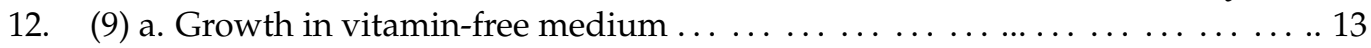

b. Growth is absent in vitamin-free medium ............... subpelliculosus

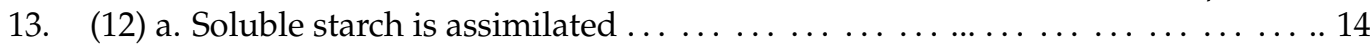

b. Soluble starch is not assimilated $\ldots \ldots \ldots \ldots \ldots \ldots \ldots \ldots \ldots \ldots$. lynferdii

14. (13) a. D-Arabinose is assimilated ...................... myanmarensis

b. D-Arabinose is not assimilated $\ldots \ldots \ldots \ldots \ldots \ldots \ldots \ldots \ldots$. anomalus

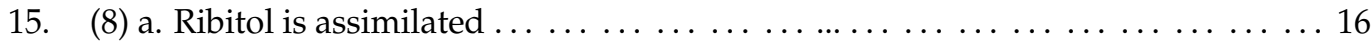

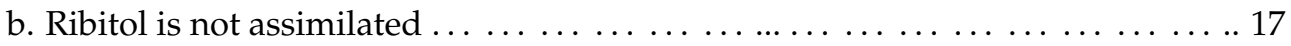

16. (15) a. Galactose is assimilated $\ldots \ldots \ldots \ldots \ldots \ldots \ldots \ldots \ldots \ldots$. strasburgensis

b. Galactose is not assimilated .......................... rabaulensis

17. (15) a. Growth in vitamin-free medium ................... patagonicus

b. Growth is absent in vitamin-free medium $\ldots \ldots \ldots \ldots \ldots \ldots \ldots \ldots \ldots$

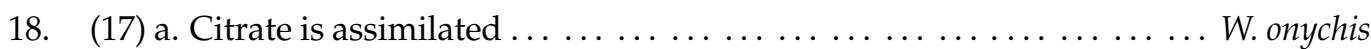

b. Citrate is not assimilated $\ldots \ldots \ldots \ldots \ldots \ldots \ldots \ldots \ldots \ldots \ldots \ldots \ldots \ldots \ldots \ldots \ldots$ siamensis

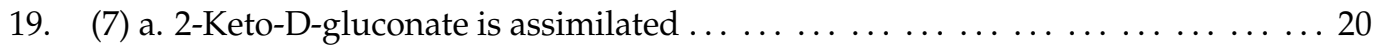

b. 2-Keto-D-gluconate is not assimilated $\ldots \ldots \ldots \ldots \ldots \ldots \ldots \ldots \ldots \ldots \ldots$ 
20. (19) a. D-Glucitol is assimilated .................... . mucosus

b. D-Glucitol is not assimilated ..................... xylosicus

21. (19) a. D-Arabinose is assimilated ...................... 22

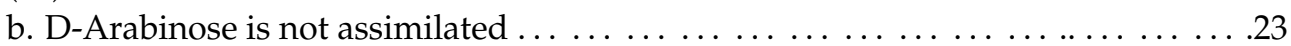

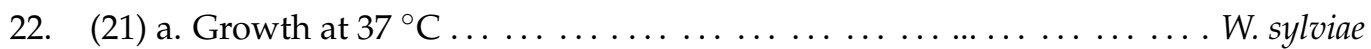

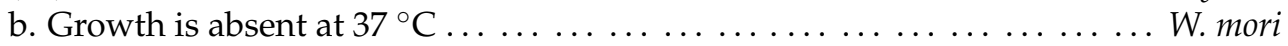

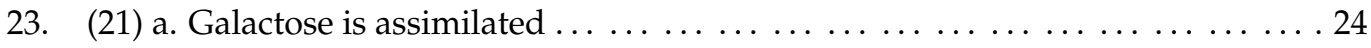

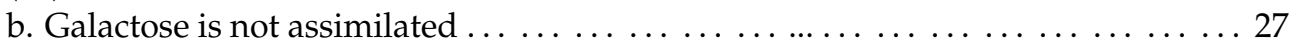

24. (23) a. L-Arabinose is assimilated $\ldots \ldots \ldots \ldots \ldots \ldots \ldots \ldots \ldots \ldots$. silvicola

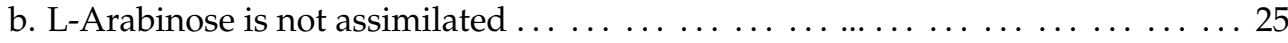

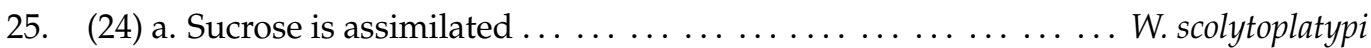

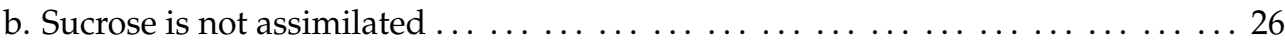

26. (24) a. D-Mannitol is assimilated ..................... nanensis

b. D-Mannitol is not assimilated ..................... chambardii

27. (23) a. L-Sorbose is assimilated ......................... pijperi

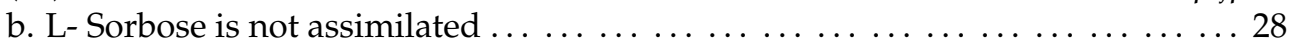

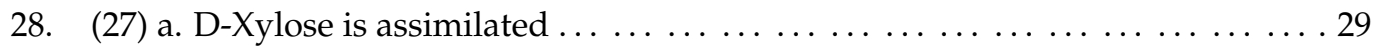

b. D-Xylose is not assimilated $\ldots \ldots \ldots \ldots \ldots \ldots \ldots \ldots \ldots \ldots$ tratensis

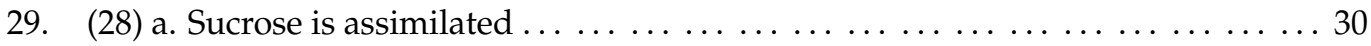

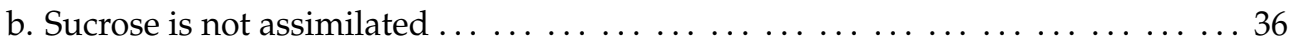

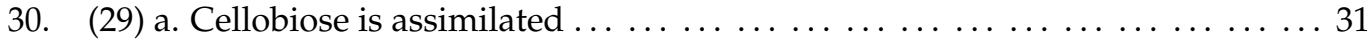

b. Cellobiose is not assimilated $\ldots \ldots \ldots \ldots \ldots \ldots \ldots \ldots \ldots \ldots$. queroliae

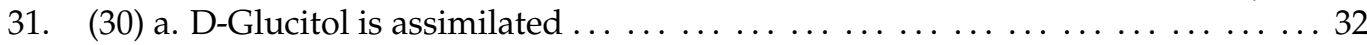

b. D-Glucitol is not assimilated ................... chaumierensis

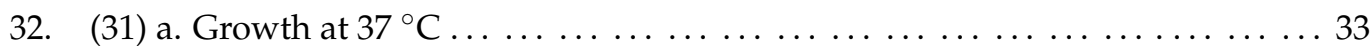

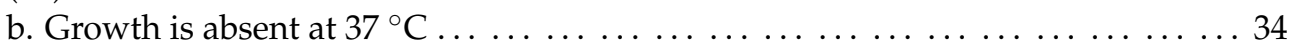

33. (32) a. L-Arabinose is assimilated ....................... bovis

b. L-Arabinose is not assimilated $\ldots \ldots \ldots \ldots \ldots \ldots \ldots \ldots$. canadensis

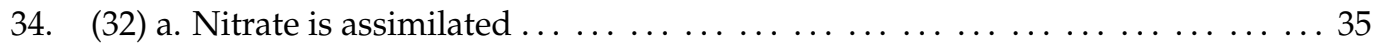

b. Nitrate is not assimilated $\ldots \ldots \ldots \ldots \ldots \ldots \ldots \ldots \ldots$. hampshirensis

35. (34) a. True hyphae are formed $\ldots \ldots \ldots \ldots \ldots \ldots \ldots \ldots \ldots \ldots \ldots$. bisporus

b. True hyphae are not formed $\ldots \ldots \ldots \ldots \ldots \ldots \ldots \ldots \ldots \ldots \ldots \ldots \ldots \ldots \ldots \ldots$

36. (29) a. Citrate is assimilated $\ldots \ldots \ldots \ldots \ldots \ldots \ldots \ldots \ldots \ldots \ldots \ldots \ldots \ldots \ldots \ldots$. menglaensis

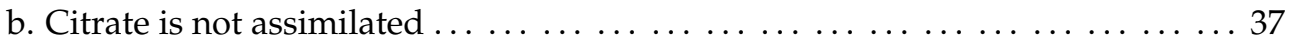

37. (36) a. Growth at $37^{\circ} \mathrm{C} \ldots \ldots \ldots \ldots \ldots \ldots \ldots \ldots \ldots$. ochangensis

b. Growth is absent at $37^{\circ} \mathrm{C} \ldots \ldots \ldots \ldots \ldots \ldots \ldots \ldots \ldots \ldots \ldots \ldots$ lannaensis 
Table 3. Key characteristics of species assigned to the genus Wickerhamomyces.

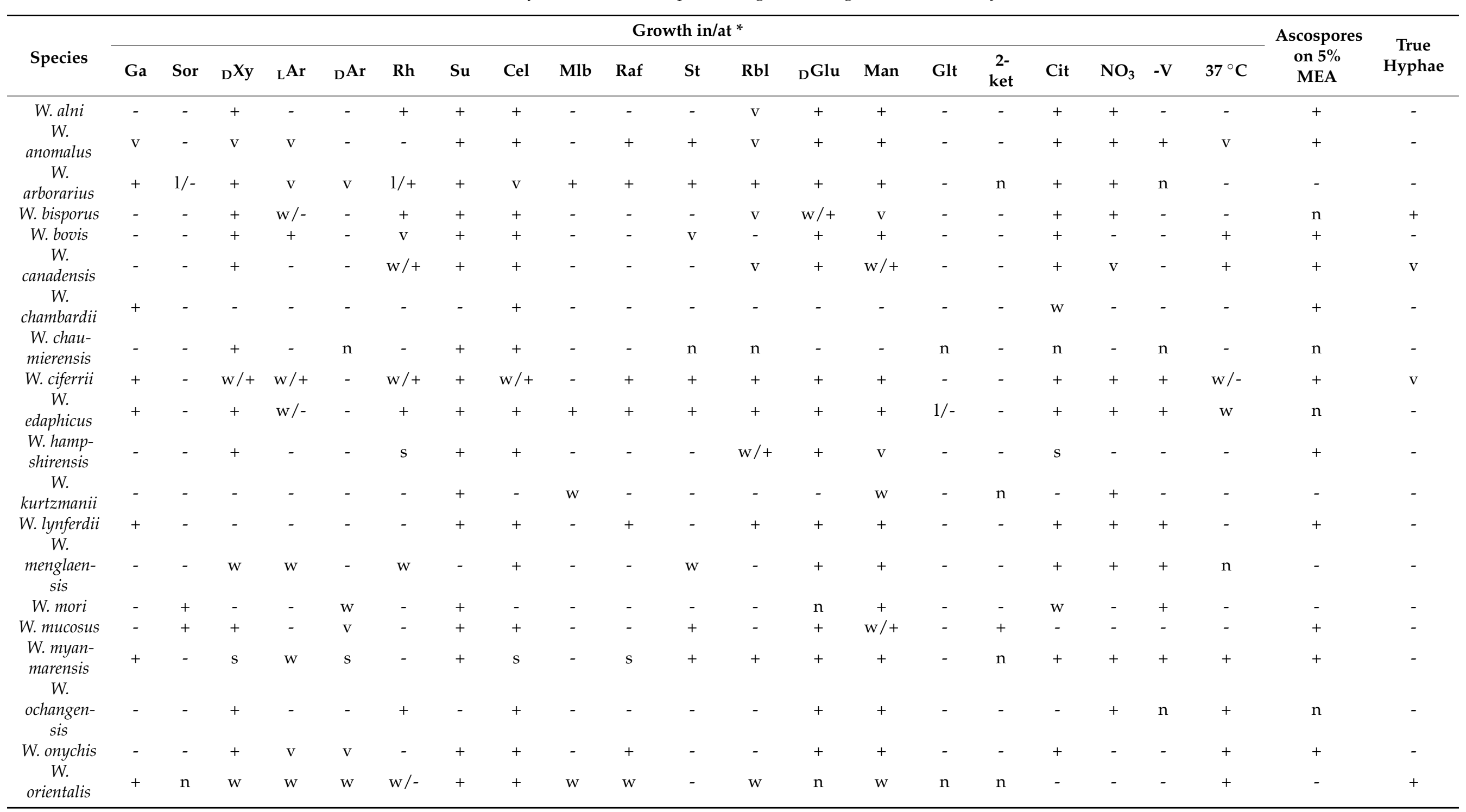


Table 3. Cont.

\begin{tabular}{|c|c|c|c|c|c|c|c|c|c|c|c|c|c|c|c|c|c|c|c|c|c|c|}
\hline \multirow[b]{2}{*}{ Species } & \multicolumn{20}{|c|}{ Growth in/at * } & \multirow{2}{*}{$\begin{array}{c}\text { Ascospores } \\
\text { on } 5 \% \\
\text { MEA }\end{array}$} & \multirow{2}{*}{$\begin{array}{c}\text { True } \\
\text { Hyphae }\end{array}$} \\
\hline & $\mathrm{Ga}$ & Sor & ${ }_{\mathrm{D}} \mathbf{X y}$ & ${ }_{\mathrm{L}} \mathrm{Ar}$ & ${ }_{\mathrm{D}}^{\mathrm{Ar}}$ & $\mathbf{R h}$ & $\mathrm{Su}$ & Cel & Mlb & Raf & St & Rbl & ${ }_{\mathrm{D}} \mathrm{Glu}$ & Man & Glt & $\begin{array}{c}2- \\
\text { ket }\end{array}$ & Cit & $\mathrm{NO}_{3}$ & $-\mathrm{V}$ & $37^{\circ} \mathrm{C}$ & & \\
\hline $\begin{array}{l}\text { W. patago- } \\
\text { nicus }\end{array}$ & $\mathrm{w}$ & - & + & - & - & + & $\mathrm{n}$ & $\mathrm{w}$ & - & $\mathrm{w}$ & $\mathrm{w}$ & - & $\mathrm{w}$ & - & - & $\mathrm{n}$ & - & - & + & - & $\mathrm{n}$ & - \\
\hline $\begin{array}{l}\text { W. pijperi } \\
\text { W. psy- }\end{array}$ & - & + & + & - & - & - & - & + & - & - & - & - & + & + & - & - & $\mathrm{v}$ & - & - & - & + & - \\
\hline $\begin{array}{l}\text { chrolipolyti- } \\
\text { cus }\end{array}$ & - & - & + & - & + & + & + & + & - & + & + & - & + & + & $\mathrm{n}$ & $\mathrm{n}$ & + & + & $\mathrm{n}$ & - & - & - \\
\hline $\begin{array}{l}\text { W. } \\
\text { rabaulensis }\end{array}$ & - & - & + & + & - & $\mathrm{v}$ & + & + & - & + & - & + & + & + & - & - & + & - & - & + & + & - \\
\hline $\begin{array}{l}\text { W. scolyto- } \\
\text { platypi }\end{array}$ & + & - & $\mathrm{s}$ & - & - & s & + & + & - & - & + & s & + & + & - & - & - & + & - & - & + & - \\
\hline $\begin{array}{c}W . \\
\text { siamensis }\end{array}$ & $\mathrm{s}$ & - & $\mathrm{s}$ & - & - & - & + & $\mathrm{w}$ & - & $\mathrm{w}$ & $\mathrm{w}$ & - & $\mathrm{w}$ & $\mathrm{w}$ & - & - & - & - & - & + & + & - \\
\hline W. silvicola & + & $\mathrm{v}$ & + & + & - & + & $\mathrm{v}$ & + & - & - & - & + & + & $\mathrm{v}$ & - & - & $\mathrm{v}$ & + & - & $\mathrm{v}$ & + & $\mathrm{v}$ \\
\hline $\begin{array}{c}\text { W. } \\
\text { spegazzinii }\end{array}$ & + & - & + & - & - & + & + & + & + & + & $\mathrm{s}$ & - & + & + & - & - & $\mathrm{w}$ & + & + & + & + & - \\
\hline $\begin{array}{l}\text { W. strasbur- } \\
\text { gensis }\end{array}$ & + & - & + & + & - & + & + & + & - & + & - & + & + & + & - & - & + & - & - & $\mathrm{v}$ & + & - \\
\hline $\begin{array}{l}\text { W. subpel- } \\
\text { liculosus }\end{array}$ & $\mathrm{v}$ & - & $\mathrm{v}$ & $\mathrm{V}$ & $\mathrm{v}$ & - & + & $\mathrm{v}$ & - & + & $\mathrm{v}$ & $\mathrm{v}$ & + & + & - & - & + & + & - & $\mathrm{v}$ & + & $\mathrm{v}$ \\
\hline $\begin{array}{l}\text { W. sydowio- } \\
\quad \text { rum }\end{array}$ & + & - & $\mathrm{v}$ & + & - & + & + & + & + & + & $\mathrm{v}$ & + & + & + & - & - & + & + & + & - & + & - \\
\hline W. sylviae & $\mathrm{v}$ & - & $\mathrm{s} /-$ & + & + &,+- & $\mathrm{w} /-$ & $\mathrm{s} /-$ & - & - & $\mathrm{w} /+$ & s/- & - & - & - & - & - & $\mathrm{v}$ & + & + & - & - \\
\hline W. tratensis & - & - & - & - & - & - & - & $\mathrm{v}$ & - & - & - & - & $\mathrm{v}$ & $\mathrm{v}$ & - & - & - & $\mathrm{n}$ & $\mathrm{n}$ & + & $\mathrm{n}$ & - \\
\hline $\begin{array}{c}W . \\
\text { xylosicus }\end{array}$ & - & + & + & - & - & - & + & + & - & - & - & - & - & + & - & $\mathrm{w}$ & - & - & $\mathrm{n}$ & - & + & - \\
\hline $\begin{array}{c}\text { W. } \\
\text { xylosivorus }\end{array}$ & $\mathrm{w} /-$ & - & + & - & - & + & - & + & - & $\mathrm{w}$ & - & - & + & - & $\mathrm{n}$ & - & - & + & + & $\mathrm{n}$ & - & - \\
\hline $\begin{array}{c}\text { W. } \\
\text { lannaensis }\end{array}$ & - & - & + & - & - & + & - & + & - & - & - & - & + & + & - & - & - & + & $\mathrm{w}$ & - & - & - \\
\hline $\begin{array}{c}W . \\
\text { nanensis }\end{array}$ & + & - & - & - & - & - & - & + & - & - & - & - & - & + & - & - & + & $\mathrm{w}$ & $\mathrm{w}$ & - & - & - \\
\hline
\end{tabular}

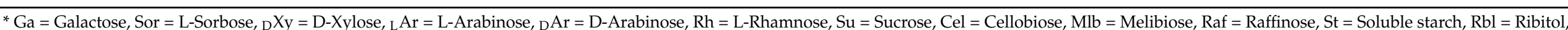

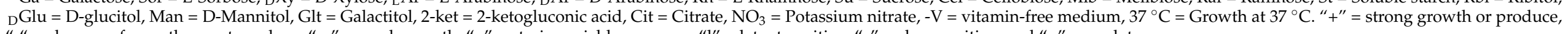
"-" = absence of growth or not produce, " $\mathrm{w}$ " = weak growth, " $\mathrm{v}$ " = strain variable response, " 1 " = latent positive, "s" = slow positive, and " $\mathrm{n}$ " = no data. 


\section{Discussion}

Traditional methods of identification and characterization for the Wickerhamomyces species are based primarily on phenotypical characteristics. These are further recognized as relevant morphological, biochemical, and physiological characteristics [41,128]. However, identification can be difficult because some species have similar appearances, and some biochemical characteristics are consistent across a number of species. In accordance with this evidence, previous species of Wickerhamomyces were originally classified into various yeast genera $[1,2,4,5,50,70,75]$. In 2008, the genus Wickerhamomyces was proposed by Kurtzman et al. [1], wherein this genus was clearly separated from other yeast genera based on phylogenetic evidence. Subsequently, some previously identified species were then transferred from the genera Candida, Hansenula, Pichia, and Williopsis $[1,4,5,50,54,70]$. Therefore, molecular phylogenetic analysis is necessary to concretely identify the Wickerhamomyces species. Species of the genus Wickerhamomyces are known to be widely distributed throughout the world and have been isolated from various habitats as shown in Table 1. Prior to conducting our study, Wickerhamomyces consisted of 35 accepted and published species according to molecular phylogenetic analysis. Our phylogenetic results were similar to those of Arastehfar et al. [8] and Shimizu et al. [65] who indicated that P. myanmarensis should be placed in the genus Wickerhamomyces. Consequently, we have proposed that this yeast species be named $W$. myanmarensis.

Yeast diversity has been investigated in various habitats throughout different regions of Thailand $[5,10,15,16,18,19,46,70,78]$. Wickerhamomyces anomalus was first species reported in Thailand in 2002 [20]. In 2009, the first new species, W. edaphicus has been discovered in Thailand [10]. Until now, a total of eight Wickerhamomyces species have been found $[5,10,20,46,68,70,78,82]$. However, $W$. siamensis, $W$. tratensis, and W. xylosicus were only known to be from Thailand $[5,70,82]$. In this study, two new Wickerhamomyces species, namely $W$. lannaensis and $W$. nanensis, that were isolated from soil collected from Assam tea plantations in northern Thailand were proposed based on identification through molecular phylogenetic and phenotypic (morphological, biochemical, and physiological characteristics) analyses. Therefore, effective identification of the Wickerhamomyces species has increased the number of species found in Thailand to 10 species and has led to 38 global species. This present discovery has increased the number of species of yeast known to be from Thailand and is considered important in terms of stimulating deeper investigations of yeast varieties in Thailand. Ultimately, these findings will help researchers gain a better understanding of the distribution and ecology of Wickerhamomyces.

Many species of the genus Wickerhamomyces have been investigated, and some strains have been used in a variety of biotechnology, food, and beverage industries, as well as in medical and agricultural fields [83-102]. Despite the fact that many Wickerhamomyces species can survive in a variety of environments, climate change has had an impact on both the terrestrial biome and the aquatic environment. These environments are known to serve as habitats for a number of microorganisms [130-134] and may have an impact on the global diversity and distribution of Wickerhamomyces. Therefore, in addition to studying the diversity and distribution of newly identified species, future research should focus on the effects of climate change on Wickerhamomyces.

Author Contributions: Conceptualization, S.N., J.K., N.S. and S.L. (Saisamorn Lumyong); methodology, S.N., J.K., N.S. and S.L. (Savitree Limtong); software, N.S. and J.K.; validation, N.S., J.K., S.L. (Savitree Limtong) and S.L. (Saisamorn Lumyong); formal analysis, S.N., J.K., N.S.; investigation, S.N., J.K. and N.S.; resources, J.K., N.S. and S.K.; data curation, N.S., J.K. and N.S.; writing-original draft, S.N., J.K. and N.S.; writing-review and editing, J.K., S.N., N.S., S.L. (Savitree Limtong) and S.L. (Saisamorn Lumyong); supervision, S.L. (Saisamorn Lumyong). All authors have read and agreed to the published version of the manuscript.

Funding: The authors gratefully acknowledge the financial support provided from Chiang Mai University, Thailand.

Institutional Review Board Statement: Not applicable. 
Informed Consent Statement: Not applicable.

Data Availability Statement: The DNA sequence data obtained from this study have been deposited in GenBank under accession numbers; D1/D2 domains (MT639220, MT623569, MT613722, MT613875 and MT623569) and ITS (OK135750, OK135752, OK135753, OK143510 and OK143511).

Acknowledgments: The authors are grateful to Russell Kirk Hollis for kind help in the English correction.

Conflicts of Interest: The authors declare no conflict of interest.

\section{References}

1. Kurtzman, C.P.; Robnett, C.J.; Basehoar-Powers, E. Phylogenetic relationships among species of Pichia, Issatchenkia and Williopsis determined from multigene sequence analysis, and the proposal of Barnettozyma gen. nov., Lindnera gen. nov. and Wickerhamomyces gen. nov. FEMS. Yeast. Res. 2008, 8, 939-954. [CrossRef] [PubMed]

2. Kurtzman, C.P. Wickerhamomyces Kurtzman, Robnett \& Basehoar-Powers. In The Yeasts; Kurtzman, C.P., Fell, J.W., Boekhout, T., Eds.; Elsevier: Amsterdam, The Netherlands, 2011; pp. 899-917.

3. Yarrow, D. Methods for the isolation, maintenance and identification of yeasts. In The Yeasts; Kurtzman, C.P., Fell, J.W., Eds.; Elsevier: Amsterdam, The Netherlands, 1998; pp. 77-100.

4. Kobayashi, R.; Kanti, A.; Kawasaki, H. Three novel species of d-xylose-assimilating yeasts, Barnettozyma xylosiphila sp. nov., Barnettozyma xylosica sp. nov. and Wickerhamomyces xylosivorus f.a., sp. nov. Int. J. Syst. Evol. Microbiol. 2017, 67, 3971-3976. [CrossRef]

5. $\quad$ Limtong, S.; Nitiyon, S.; Kaewwichian, R.; Jindamorakot, S.; Am-In, S.; Yongmanitchai, W. Wickerhamomyces xylosica sp. nov. and Candida phayaonensis sp. nov., two xylose-assimilating yeast species from soil. Int. J. Syst. Evol. Microbiol. 2012, 62, $2786-2792$. [CrossRef]

6. Zhou, Y.; Jia, B.S.; Han, P.J.; Wang, Q.M.; Li, A.H.; Zhou, Y.G. Wickerhamomyces kurtzmanii sp. nov. an ascomycetous yeast isolated from crater lake water, Da Hinggan Ling Mountain, China. Curr. Microbiol. 2019, 76, 1537-1544. [CrossRef] [PubMed]

7. Index Fungorum. Available online: http:/ / www.indexfungorum.org (accessed on 25 July 2021).

8. Arastehfar, A.; Bakhtiari, M.; Daneshnia, F.; Fang, W.; Sadati, S.K.; Al-Hatmi, A.M.; Groenewald, M.; Sharifi-Mehr, H.; Liao, W.; Pan, W.; et al. First fungemia case due to environmental yeast Wickerhamomyces myanmarensis: Detection by multiplex qPCR and antifungal susceptibility. Future Microbiol. 2019, 14, 267-274. [CrossRef] [PubMed]

9. Nagatsuka, Y.; Kawasaki, H.; Seki, T. Pichia myanmarensis sp. nov., a novel cation-tolerant yeast isolated from palm sugar in Myanmar. Int. J. Syst. Evol. Microbiol. 2005, 55, 1379-1382. [CrossRef] [PubMed]

10. Limtong, S.; Yongmanitchai, W.; Kawasaki, H.; Fujiyama, K. Wickerhamomyces edaphicus sp. nov. and Pichia jaroonii sp. nov., two ascomycetous yeast species isolated from forest soil in Thailand. FEMS Yeast Res. 2009, 9, 504-510. [CrossRef] [PubMed]

11. Shin, K.S.; Bae, K.S.; Lee, K.H.; Park, D.S.; Kwon, G.S.; Lee, J.B. Wickerhamomyces ochangensis sp. nov., an ascomycetous yeast isolated from the soil of a potato field. Int. J. Syst. Evol. Microbiol. 2011, 61, 2543-2546. [CrossRef]

12. Phaff, H.J.; Miller, M.W.; Miranda, M. Hansenula alni, a new heterothallic species of yeast from exudates of alder trees. Int. J. Syst. Evol. 1979, 29, 60-63. [CrossRef]

13. Hansen, E.C. Sur la germination des spores chez les Saccharomyces. Ann. Microgr. 1891, 3, 449-474.

14. Sláviková, E.; Vadkertiová, R.; Vránová, D. Yeasts colonizing the leaf surfaces. J. Basic Microbiol. 2007, 47, 344-350. [CrossRef]

15. Into, P.; Pontes, A.; Sampaio, J.P.; Limtong, S. Yeast diversity associated with the phylloplane of corn plants cultivated in Thailand. Microorganisms 2020, 8, 80. [CrossRef] [PubMed]

16. Kumla, J.; Nundaeng, S.; Suwannarach, N.; Lumyong, S. Evaluation of multifarious plant growth promoting trials of yeast isolated from the soil of Assam tea (Camellia sinensis var. assamica) plantations in Northern Thailand. Microorganisms 2020, 8, 1168. [CrossRef]

17. Carrasco, M.; Rozas, J.M.; Barahona, S.; Alcaíno, J.; Cifuentes, V.; Baeza, M. Diversity and extracellular enzymatic activities of yeasts isolated from King George Island, the sub-Antarctic region. BMC Microbiol. 2012, 12, 251. [CrossRef]

18. Kaewkrajay, C.; Chanmethakul, T.; Limtong, S. Assessment of diversity of culturable marine yeasts associated with corals and zoanthids in the gulf of Thailand, South China Sea. Microorganisms 2020, 8, 474. [CrossRef] [PubMed]

19. Satianpakiranakorn, P.; Khunnamwong, P.; Limtong, S. Yeast communities of secondary peat swamp forests in Thailand and their antagonistic activities against fungal pathogens cause of plant and postharvest fruit diseases. PLoS ONE 2020, 15, e0230269. [CrossRef] [PubMed]

20. Limtong, S.; Sintara, S.; Suwannarit, P.; Lotong, N. Yeast diversity in Thai traditional alcoholic starter. Kasetsart J. (Nat. Sci.) 2002, 36, 149-158.

21. Hoondee, P.; Wattanagonniyom, T.; Weeraphan, T.; Tanasupawat, S.; Savarajara, A. Occurrence of oleaginous yeast from mangrove forest in Thailand. World J. Microbiol. Biotechnol. 2019, 35, 108. [CrossRef] [PubMed]

22. Tepeeva, A.N.; Glushakova, A.M.; Kachalkin, A.V. Yeast communities of the Moscow city soils. Microbiology 2018, 87, 407-415. [CrossRef]

23. Koricha, A.D.; Han, D.Y.; Bacha, K.; Bai, F.Y. Diversity and distribution of yeasts in indigenous fermented foods and beverages of Ethiopia. J. Sci. Food Agric. 2020, 100, 3630-3638. [CrossRef] [PubMed] 
24. Vadkertiová, R.; Molnárová, J.; Vránová, D.; Sláviková, E. Yeasts and yeast-like organisms associated with fruits and blossoms of different fruit trees. Can. J. Microbiol. 2012, 58, 1344-1352. [CrossRef] [PubMed]

25. PrasannaKumar, C.; Velmurugan, S.; Subramanian, K.; Pugazhvendan, S.R.; Nagaraj, D.S.; Khan, K.F.; Sadiappan, B.; Manokaran, S.; Hemalatha, K.R. DNA barcoding analysis of more than 1000 marine yeast isolates reveals previously unrecorded species. BioRxiv 2020, 1-39.

26. Abu-Mejdad, N.M.J.A.; Al-Badran, A.I.; Al-Saadoon, A.H.; Minati, M.H. A new report on gene expression of three killer toxin genes with antimicrobial activity of two killer toxins in Iraq. Bull. Natl. Res. Cent. 2020, 44, 162. [CrossRef]

27. Horváth, E.; Sipiczki, M.; Csoma, H.; Miklós, I. Assaying the effect of yeasts on growth of fungi associated with disease. BMC Microbiol. 2020, 20, 320. [CrossRef]

28. Hamoudi-Belarbi, L.; Nouri, L.H.; Belkacemi, K. Effectiveness of convective drying to conserve indigenous yeasts with high volatile profile isolated from algerian fermented raw bovine milk (Rayeb). J. Food Sci. Technol. 2016, 36, 476-484. [CrossRef]

29. You, L.; Wang, S.; Zhou, R.; Hu, X.; Chu, Y.; Wang, T. Characteristics of yeast flora in Chinese strong-flavoured liquor fermentation in the Yibin region of China. J. Inst. Brew. 2016, 122, 517-523. [CrossRef]

30. Borling Welin, J.; Lyberg, K.; Passoth, V.; Olstorpe, M. Combined moist airtight storage and feed fermentation of barley by the yeast Wickerhamomyces anomalus and a lactic acid bacteria consortium. Front. Plant. Sci. 2015, 6, 270. [CrossRef] [PubMed]

31. Pires, J.F.; de Souza Cardoso, L.; Schwan, R.F.; Silva, C.F. Diversity of microbiota found in coffee processing wastewater treatment plant. World J. Microbiol. Biotechnol. 2017, 33, 211. [CrossRef] [PubMed]

32. Delgado-Ospina, J.; Triboletti, S.; Alessandria, V.; Serio, A.; Sergi, M.; Paparella, A.; Rantsiou, K.; Chaves-López, C. Functional biodiversity of yeasts isolated from Colombian fermented and dry cocoa beans. Microorganisms 2020, 8, 1086. [CrossRef] [PubMed]

33. da Conceição, L.E.F.R.; Saraiva, M.A.F.; Diniz, R.H.S.; Oliveira, J.; Barbosa, G.D.; Alvarez, F.; Correa, L.F.; Mezadri, H.; Coutrim, M.X.; Afonso, R.J.; et al. Biotechnological potential of yeast isolates from cachaça: The Brazilian spirit. J. Ind. Microbiol. Biotechnol. 2015, 42, 237-246. [CrossRef] [PubMed]

34. Da Cunha, A.C.; Gomes, L.S.; Godoy-Santos, F.; Faria-Oliveira, F.; Teixeira, J.A.; Sampaio, G.M.S.; Trópia, M.J.M.; Castro, I.M.; Lucas, C.; Brandão, R.L. High-affinity transport, cyanide-resistant respiration, and ethanol production under aerobiosis underlying efficient high glycerol consumption by Wickerhamomyces anomalus. J. Ind. Microbiol. Biotechnol. 2019, 46, 709-723. [CrossRef] [PubMed]

35. Cunha, A.C.; Santos, R.A.; Riaño-Pachon, D.M.; Squina, F.M.; Oliveira, J.V.; Goldman, G.H.; Souza, A.T.; Gomes, L.S.; GodoySantos, F.; Teixeira, J.A. Draft genome sequence of Wickerhamomyces anomalus LBCM1105, isolated from cachaça fermentation. Genet. Mol. Biol. 2020, 43, 1-5. [CrossRef] [PubMed]

36. James, S.A.; Barriga, E.J.C.; Barahona, P.P.; Harrington, T.C.; Lee, C.F.; Bond, C.J.; Roberts, I.N. Wickerhamomyces arborarius fa, sp. nov., an ascomycetous yeast species found in arboreal habitats on three different continents. Int. J. Syst. Evol. 2014, 64, 1057-1061. [CrossRef]

37. Beck, O. Eine neue Endomyces-Art, Endomyces bisporus. Ann. Mycol. 1922, 20, $219-227$.

38. Linnakoski, R.; Lasarov, I.; Veteli, P.; Tikkanen, O.P.; Viiri, H.; Jyske, T.; Kasanen, R.; Duong, T.A.; Wingfield, M.J. Filamentous fungi and yeasts associated with mites phoretic on Ips typographus in eastern Finland. Forests 2021, 12, 743. [CrossRef]

39. Dohet, L.; Gregoire, J.C.; Berasategui, A.; Kaltenpoth, M.; Biedermann, P.H. Bacterial and fungal symbionts of parasitic Dendroctonus bark beetles. FEMS Microbiol. Ecol. 2016, 92, fiw129. [CrossRef] [PubMed]

40. Uden, V.N.; Carmo Souza, L.D. Yeast from the bovine caecum. J. Gen. Microbiol. 1957, 16, 385-395. [CrossRef] [PubMed]

41. Wickerham, L.J. Taxonomy of Yeasts; U.S. Department of Agriculture: Washington, DC, USA, 1951; pp. 1-56.

42. Ramirez, C. Note sur deux nouvelles espèces de levures isolées de divers milieux. Rev. Mycol. 1954, 19, 98-102.

43. Groenewald, M.; Robert, V.; Smith, M.T. Five novel Wickerhamomyces-and Metschnikowia-related yeast species, Wickerhamomyces chaumierensis sp. nov., Candida pseudoflosculorum sp. nov., Candida danieliae sp. nov., Candida robnettiae sp. nov. and Candida eppingiae sp. nov., isolated from plants. Int. J. Syst. Evol. 2011, 61, 2015-2022. [CrossRef] [PubMed]

44. Lodder, J. Über einige durch das "Centraalbureau voor Schimmelcultures” neuerworbene sporogene Hefearten. Zentralbl. Bakteriol. Parasitenkd. Abt. II 1932, 86, 227-253.

45. Sitepu, I.R.; Enriquez, L.L.; Nguyen, V.; Doyle, C.; Simmons, B.A.; Singer, S.W.; Fry, R.; Simmons, C.W.; Boundy-Mills, K. Ethanol production in switchgrass hydrolysate by ionic liquid-tolerant yeasts. Bioresour. Technol. Rep. 2019, 7, 100275. [CrossRef]

46. Limtong, S.; Kaewwichian, R. The diversity of culturable yeasts in the phylloplane of rice in Thailand. Ann. Microbiol. 2015, 65, 667-675. [CrossRef]

47. Patel, K.; Patel, F.R. Optimization of culture conditions for biosurfactant production by Wickerhamomyces edaphicus isolated from mangrove region of Mundra, Kutch, Gujarat. Indian J. Sci. Technol. 2020, 13, 1935-1943. [CrossRef]

48. Kurtzman, C.P. Two new species of Pichia from arboreal habitats. Mycologia 1987, 79, 410-417. [CrossRef]

49. Suh, S.O.; Zhou, J. Yeasts associated with the curculionid beetle Xyloterinus politus: Candida xyloterini sp. nov., Candida palmyrensis sp. nov. and three common ambrosia yeasts. Int. J. Syst. Evol. Microbiol. 2010, 60, 1702-1708. [CrossRef]

50. van der Walt, J.P.; Johannsen, E. Hansenula lynferdii sp. nov. Antonie Van Leeuwenhoek 1975, 41, 13-16. [CrossRef]

51. Chai, C.Y.; Huang, L.N.; Cheng, H.; Liu, W.J.; Hui, F.L. Wickerhamomyces menglaensis fa, sp. nov., a yeast species isolated from rotten wood. Int. J. Syst. Evol. Microbiol. 2019, 69, 1509-1514. [CrossRef] [PubMed]

52. Hui, F.L.; Chen, L.; Chu, X.Y.; Niu, Q.H.; Ke, T. Wickerhamomyces mori sp. nov., an anamorphic yeast species found in the guts of wood-boring insect larvae. Int. J. Syst. Evol. Microbiol. 2013, 63, 1174-1178. [CrossRef] [PubMed] 
53. Wlckerham, L.J.; Kurtzman, C.P. Two new saturn-spored species of Pichia. Mycologia 1971, 63, 1013-1018. [CrossRef]

54. Yarrow, D. Pichia onychis sp. n. Antonie Van Leeuwenhoek. J. Microbiol. Serol. 1965, 31, 465-467.

55. Cioch-Skoneczny, M.; Satora, P.; Skoneczny, S.; Skotniczny, M. Biodiversity of yeasts isolated during spontaneous fermentation of cool climate grape musts. Arch. Microbiol. 2021, 203, 153-162. [CrossRef]

56. Abu-Mejdad, N.M.J.A.; Al-Badran, A.I.; Al-Saadoon, A.H. New record of ascomycetous yeasts strains from soil in Basrah, Iraq. Drug Invent. Today. 2019, 11, 3073-3080.

57. Bah, A.; Ferjani, R.; Fhoula, I.; Gharbi, Y.; Najjari, A.; Boudabous, A.; Ouzari, H.I. Microbial community dynamic in tomato fruit during spontaneous fermentation and biotechnological characterization of indigenous lactic acid bacteria. Ann. Microbiol. 2019, 69, 41-49. [CrossRef]

58. Ooi, T.S.; Sepiah, M.; Khairul Bariah, S. Diversity of yeast species identified during spontaneous shallow box fermentation of cocoa beans in Malaysia. Int. J. Eng. Innov. Technol. 2016, 3, 379-385.

59. Maciel, N.O.; Johann, S.; Brandão, L.R.; Kucharíková, S.; Morais, C.G.; Oliveira, A.P.; Freitas, G.J.; Borelli, B.M.; Pellizzari, F.M.; Santos, D.A.; et al. Occurrence, antifungal susceptibility, and virulence factors of opportunistic yeasts isolated from Brazilian beaches. Mem. Inst. Oswaldo Cruz 2019, 114, 114. [CrossRef] [PubMed]

60. Nasr, S.; Nguyen, H.D.; Soudi, M.R.; Fazeli, S.A.S.; Sipiczki, M. Wickerhamomyces orientalis fa, sp. nov.: An ascomycetous yeast species belonging to the Wickerhamomyces clade. Int. J. Syst. Evol. Microbiol. 2016, 66, 2534-2539. [CrossRef]

61. de García, V.; Brizzio, S.; Libkind, D.; Rosa, C.A.; van Broock, M. Wickerhamomyces patagonicus sp. nov., an ascomycetous yeast species from Patagonia, Argentina. Int. J. Syst. Evol. Microbiol. 2010, 60, 1693-1696. [CrossRef] [PubMed]

62. van Walt, J.P.; Tscheuschner, I.T. Three new yeasts. Antonie Van Leeuwenhoek 1957, 23, 184-190. [CrossRef]

63. Nielsen, D.S.; Teniola, O.D.; Ban-Koffi, L.; Owusu, M.; Andersson, T.S.; Holzapfel, W.H. The microbiology of Ghanaian cocoa fermentations analysed using culture-dependent and culture-independent methods. Int. J. Food Microbiol. 2007, 114, 168-186. [CrossRef] [PubMed]

64. Abdel-Sater, M.A.; Moubasher, A.H.; Zeinab, S.M. Diversity of yeasts and filamentous fungi in five fresh fruit juices in Egypt. Curr. Res. Environ. 2017, 7, 356-386. [CrossRef]

65. Shimizu, Y.; Konno, Y.; Tomita, Y. Wickerhamomyces psychrolipolyticus fa, sp. nov., a novel yeast species producing two kinds of lipases with activity at different temperatures. Int. J. Syst. Evol. 2020, 70, 1158-1165. [CrossRef] [PubMed]

66. Rosa, C.A.; Morais, P.B.; Lachance, M.A.; Santos, R.O.; Melo, W.G.; Viana, R.H.; Bragança, M.A.; Pimenta, R.S. Wickerhamomyces queroliae sp. nov. and Candida jalapaonensis sp. nov., two yeast species isolated from Cerrado ecosystem in North Brazil. Int. J. Syst. Evol. Microbiol. 2009, 59, 1232-1236. [CrossRef] [PubMed]

67. Soneda, M.; Uchida, S. A survey on the yeasts. Bull. Nat. Science Museum 1971, 14, 451-453.

68. Junyapate, K.; Jindamorakot, S.; Limtong, S. Yamadazyma ubonensis fa, sp. nov., a novel xylitol-producing yeast species isolated in Thailand. Antonie Van Leeuwenhoek 2014, 105, 471-480. [CrossRef]

69. Ninomiya, S.; Mikata, K.; Kajimura, H.; Kawasaki, H. Two novel ascomycetous yeast species, Wickerhamomyces scolytoplatypi sp. nov. and Cyberlindnera xylebori sp. nov., isolated from ambrosia beetle galleries. Int. J. Syst. Evol. Microbiol. 2013, 63, $2706-2711$. [CrossRef] [PubMed]

70. Kaewwichian, R.; Kawasaki, H.; Limtong, S. Wickerhamomyces siamensis sp. nov., a novel yeast species isolated from the phylloplane in Thailand. Int. J. Syst. Evol. Microbiol. 2013, 63, 1568-1573. [CrossRef] [PubMed]

71. Bien, S.; Damm, U. Prunus trees in Germany-A hideout of unknown fungi? Mycol. Prog. 2020, 19, 667-690. [CrossRef]

72. Hyun, S.H.; Min, J.H.; Lee, H.B.; Kim, H.K.; Lee, J.S. Characteristics of two unrecorded yeasts from wildflowers in Ulleungdo, Korea. Kor. J. Mycol. 2014, 42, 170-173. [CrossRef]

73. Masiulionis, V.E.; Pagnocca, F.C. Wickerhamomyces spegazzinii sp. nov., an ascomycetous yeast isolated from the fungus garden of Acromyrmex lundii nest (Hymenoptera: Formicidae). Int. J. Syst. Evol. Microbiol. 2016, 66, 2141-2145. [CrossRef] [PubMed]

74. Ramírez, C.; Boidin, J. Saccharomyces chambardi, nouvelle espèce de levure isolée de liqueur tannante. De La Société Linnéenne De Lyon 1954, 23, 151-152. [CrossRef]

75. Kurtzman, C.P. Synonomy of the yeast genera Hansenula and Pichia demonstrated through comparisons of deoxyribonucleic acid relatedness. Antonie Van Leeuwenhoek 1984, 50, 209-217. [CrossRef]

76. Moubasher, A.H.; Abdel-Sater, M.A.; Soliman, Z. Yeasts and filamentous fungi inhabiting guts of three insect species in Assiut, Egypt. Mycosphere 2017, 8, 1297-1316. [CrossRef]

77. Scott, D.B.; Van der Walt, J.P. Hansenula sydowiorum sp. n. Antonie Van Leeuwenhoek 1970, 36, 45-48. [CrossRef] [PubMed]

78. Boonmak, C.; Jindamorakot, S.; Kawasaki, H.; Yongmanitchai, W.; Suwanarit, P.; Nakase, T.; Limtong, S. Candida siamensis sp. nov., an anamorphic yeast species in the Saturnispora clade isolated in Thailand. FEMS Yeast Res. 2009, 9, 668-672. [CrossRef] [PubMed]

79. Samagaci, L.; Ouattara, H.; Niamké, S.; Lemaire, M. Pichia kudrazevii and Candida nitrativorans are the most well-adapted and relevant yeast species fermenting cocoa in Agneby-Tiassa, a local Ivorian cocoa producing region. Int. Food Res. J. 2016, 89, 773-780. [CrossRef] [PubMed]

80. Echeverrigaray, S.; Scariot, F.J.; Foresti, L.; Schwarz, L.V.; Rocha, R.K.M.; da Silva, G.P.; Moreira, J.P.; Delamare, A.P.L. Yeast biodiversity in honey produced by stingless bees raised in the highlands of southern Brazil. Int. J. Food Microbiol. 2021, $347,109200$. [CrossRef] [PubMed] 
81. Francesca, N.; Carvalho, C.; Almeida, P.M.; Sannino, C.; Settanni, L.; Sampaio, J.P.; Moschetti, G. Wickerhamomyces sylviae f.a., sp. nov., an ascomycetous yeast species isolated from migratory birds. Int. J. Syst. Evol. Microbiol. 2013, 63, 4824-4830. [CrossRef] [PubMed]

82. Nakase, T.; Jindamorakot, S.; Am-In, S.; Ninomiya, S.; Kawasaki, H. Wickerhamomyces tratensis sp. nov. and Candida namnaoensis sp. nov., two novel ascomycetous yeast species in the Wickerhamomyces clade found in Thailand. J. Gen. Appl. Microbiol. 2012, 58, 145-152. [CrossRef]

83. Ravasio, D.; Carlin, S.; Boekhout, T.; Groenewald, M.; Vrhovsek, U.; Walther, A.; Wendland, J. Adding flavor to beverages with non-conventional yeasts. Fermentation 2018, 4, 15. [CrossRef]

84. Yan, S.; Xiangsong, C.; Xiang, X. Improvement of the aroma of lily rice wine by using aroma-producing yeast strain Wickerhamomyces anomalus HN006. AMB Express 2019, 9, 89. [CrossRef]

85. Li, W.; Shi, C.; Guang, J.; Ge, F.; Yan, S. Development of Chinese chestnut whiskey: Yeast strains isolation, fermentation system optimization, and scale-up fermentation. AMB Express 2021, 11, 17. [CrossRef] [PubMed]

86. Czarnecka, M.; Żarowska, B.; Połomska, X.; Restuccia, C.; Cirvilleri, G. Role of biocontrol yeasts Debaryomyces hansenii and Wickerhamomyces anomalus in plants' defence mechanisms against Monilinia fructicola in apple fruits. Food Microbiol. 2019, 83, 1-8. [CrossRef]

87. Limtong, S.; Into, P.; Attarat, P. Biocontrol of rice seedling rot disease caused by Curvularia lunata and Helminthosporium oryzae by epiphytic yeasts from plant leaves. Microorganisms 2020, 8, 647. [CrossRef] [PubMed]

88. Lima, J.R.; Gondim, D.M.F.; Oliveira, J.T.A.; Oliveira, F.S.A.; Gonçalves, L.R.B.; Viana, F.M.P. Use of killer yeast in the management of postharvest papaya anthracnose. Postharvest Biol. Technol. 2013, 83, 58-64. [CrossRef]

89. Fernandez-San Millan, A.; Farran, I.; Larraya, L.; Ancin, M.; Arregui, L.M.; Veramendi, J. Plant growth-promoting traits of yeasts isolated from Spanish vineyards: Benefits for seedling development. Microbiol. Res. 2020, 237, 126480. [CrossRef]

90. Walker, G.M. Pichia anomala: Cell physiology and biotechnology relative to other yeasts. Antonie Van Leeuwenhoek 2011, 99, 25-34. [CrossRef] [PubMed]

91. Passoth, V.; Olstorpe, M.; Schnürer, J. Past, present and future research directions with Pichia anomala. Antonie Van Leeuwenhoek 2011, 99, 121-125. [CrossRef] [PubMed]

92. Golubev, W.I. Antifungal activity of Wickerhamomyces silvicola. Microbiology 2015, 84, 610-615. [CrossRef]

93. Golubev, W.I. Taxonomic specificity of the sensitivity to the Wickerhamomyces bovis fungistatic mycocin. Microbiology 2016, 85, 444-448. [CrossRef]

94. Silva, C.F.; Schwan, R.F.; Dias, Ë.S.; Wheals, A.E. Microbial diversity during maturation and natural processing of coffee cherries of Coffea arabica in Brazil. Int. J. Food Microbiol. 2000, 60, 251-260. [CrossRef]

95. Zhou, N.; Schifferdecker, A.J.; Gamero, A.; Compagno, C.; Boekhout, T.; Piškur, J.; Knecht, W. Kazachstania gamospora and Wickerhamomyces subpelliculosus: Two alternative baker's yeasts in the modern bakery. Int. J. Food Microbiol. 2017, 250, 45-58. [CrossRef] [PubMed]

96. Adelabu, B.; Kareem, S.; Oluwafemi, F.; Adeogun, A. Consolidated bioprocessing of ethanol from corn straw by Saccharomyces diastaticus and Wikerhamomyces chambardii. Food Appl. Biosci. J. 2018, 6, 1-17.

97. Adelabu, B.; Kareem, S.O.; Adeogun, A.I.; Wakil, S.M. Optimization of cellulase enzyme from sorghum straw by yeasts isolated from plant feeding-termite Zonocerus variegatus. Food Appl. Biosci. J. 2019, 7, 81-101.

98. Dejwatthanakomol, C.; Anuntagool, J.; Morikawa, M.; Thaniyavarn, J. Production of biosurfactant by Wickerhamomyces anomalus PY189 and its application in lemongrass oil encapsulation. Sci. Asia. 2016, 42, 252-258. [CrossRef]

99. Fernandes, N.D.A.T.; de Souza, A.C.; Simoes, L.A.; Dos Reis, G.M.F.; Souza, K.T.; Schwan, R.F.; Dias, D.R. Eco-friendly biosurfactant from Wickerhamomyces anomalus CCMA 0358 as larvicidal and antimicrobial. Microbiol. Res. 2020, $241,126571$. [CrossRef]

100. Samadlouie, H.R.; Nurmohamadi, S.; Moradpoor, F.; Gharanjik, S. Effect of low-cost substrate on the fatty acid profiles of Mortierella alpina CBS 754.68 and Wickerhamomyces siamensis SAKSG. Biotechnol. Biotechnol. Equip. 2018, 32, 1228-1235. [CrossRef]

101. Palladino, F.; Rodrigues, R.C.; Cadete, R.M.; Barros, K.O.; Rosa, C.A. Novel potential yeast strains for the biotechnological production of xylitol from sugarcane bagasse. Biofuels Bioprod. Biorefining 2021, 15, 690-702. [CrossRef]

102. Seymour, F.R.; Slodki, M.E.; Plattner, R.D.; Stodola, R.M. Methylation and acetolysis of extracellular D-mannans from yeast. Carbohydr. Res. 1976, 48, 225-237. [CrossRef]

103. Dufour, J.P.; Verstrepen, K.; Derdelinckx, G. Brewing yeasts. In Yeasts in Food; Boekhout, T., Robert, V., Eds.; Elsevier: Amsterdam, The Netherlands, 2003; pp. 347-388.

104. Timke, M.; Wang-Lieu, N.Q.; Altendorf, K.; Lipski, A. Fatty acid analysis and spoilage potential of biofilms from two breweries. J. Appl. Microbiol. 2005, 99, 1108-1122. [CrossRef] [PubMed]

105. Bonjean, B.; Guillaume, L.D. Yeasts in bread and baking products. In Yeasts in Food; Boekhout, T., Robert, V., Eds.; Elsevier: Amsterdam, The Netherlands, 2003; pp. 289-307.

106. Lanciotti, R.; Sinigaglia, M.; Gardini, F.; Guerzoni, M.E. Hansenula anomala as spoilage agent of cream-filled cakes. Microbiol. Res. 1998, 153, 145-148. [CrossRef]

107. Paula, C.R.; Krebs, V.L.; Auler, M.E.; Ruiz, L.S.; Matsumoto, F.E.; Silva, E.H.; Diniz, E.M.; Vaz, F.A. Nosocomial infection in newborns by Pichia anomala in a Brazilian intensive care unit. Med. Mycol. 2006, 44, 479-484. [CrossRef] 
108. Linton, C.J.; Borman, A.M.; Cheung, G.; Holmes, A.D.; Szekely, A.; Palmer, M.D.; Bridge, P.D.; Campbell, C.K.; Johnson, E.M. Molecular identification of unusual pathogenic yeast isolates by large ribosomal subunit gene sequencing: 2 years of experience at the United Kingdom Mycology Reference Laboratory. J. Clin. Microbiol. 2007, 45, 1152-1158. [CrossRef] [PubMed]

109. Oliveira, V.K.P.; Ruiz, L.d.S.; Oliveira, N.A.J.; Moreira, D.; Hahn, R.C.; Melo, A.S.d.A.; Nishikaku, A.S.; Paula, C.R. Fungemia caused by Candida species in a children's public hospital in the city of São Paulo, Brazil: Study in the period $2007-2010$. Rev. Do Inst. De Med. Trop. De São Paulo 2014, 56, 301-305. [CrossRef] [PubMed]

110. Kamoshita, M.; Matsumoto, Y.; Nishimura, K.; Katono, Y.; Murata, M.; Ozawa, Y.; Shimmura, S.; Tsubota, K. Wickerhamomyces anomalus fungal keratitis responds to topical treatment with antifungal micafungin. J. Infect. Chemother. 2015, 21, 141-143. [CrossRef] [PubMed]

111. Dutra, V.R.; Silva, L.F.; Oliveira, A.N.M.; Beirigo, E.F.; Arthur, V.M.; da Silva, R.B.; Ferreira, T.B.; Andrade-Silva, L.; Silva, M.V.; Fonseca, F.M.; et al. Fatal case of fungemia by Wickerhamomyces anomalus in a pediatric patient diagnosed in a teaching hospital from Brazil. J. Fungi 2020, 6, 147. [CrossRef] [PubMed]

112. De Hoog, G.S. Risk assessment of fungi reported from humans and animals. Mycoses 1996, 39, 407-417. [CrossRef] [PubMed]

113. Hyde, K.D.; Norphanphoun, C.; Chen, J.; Dissanayake, A.J.; Doilom, M.; Hongsanan, S.; Jayawardena, R.S.; Jeewon, R.; Perera, R.H.; Thongbai, B.; et al. Thailand's amazing diversity: Up to $96 \%$ of fungi in northern Thailand may be novel. Fungal Divers. 2018, 93, 215-239. [CrossRef]

114. Kumla, J.; Suwannarach, N.; Wannathes, W. Hymenagaricus saisamornae sp. nov. (Agaricales, Basidiomycota) from northern Thailand. Chiang Mai J. Sci. 2021, 48, 827-836.

115. Nakase, T.; Suzuki, M. Bullera intermedia sp. nov. and Sporobolomyces oryzicola sp. nov. isolated from dead leaves of Oryza sativa. J. Gen. Appl. Microbiol. 1986, 32, 149-155. [CrossRef]

116. Hagler, A.N.; Ahearn, D.G. Rapid diazonium blue B test to detect basidiomycetous yeasts. Int. J. Syst. Evol. 1981, 31, 204-208. [CrossRef]

117. White, T.J.; Bruns, T.; Lee, S.; Taylor, J. Amplification and direct sequencing of fungal ribosomal RNA genes for phylogenetics. In PCR Protocols: A Guide to Methods and Applications; Innis, M.A., Gelfand, D.H., Sninsky, J.J., White, T.J., Eds.; Academic Press: San Diego, CA, USA, 1990; pp. 315-322.

118. Kurtzman, C.P. DNA relatedness among saturn-spored yeasts assigned to the genera Williopsis and Pichia. Antonie Van Leeuwenhoek 1991, 60, 13-19. [CrossRef] [PubMed]

119. Edgar, R.C. MUSCLE: A multiple sequence alignment method with reduced time and space complexity. BMC Bioinform 2004, 5, 113. [CrossRef]

120. Miller, M.A.; Pfeiffer, W.; Schwartz, T. Creating the cipres science gateway for inference of large phylogenetic trees. In Proceedings of the 2010 Gateway Computing EnvironmentsWorkshop (GCE), New Orleans, LA, USA, 14 November 2010; IEEE: Manhattan, NY, USA; pp. 1-8.

121. Darriba, D.; Taboada, G.L.; Doallo, R.; Posada, D. jModelTest 2: More models, new heuristics and parallel computing. Nat. Methods. 2012, 9, 772. [CrossRef] [PubMed]

122. Ronquist, F.; Huelsenbeck, J.P. MrBayes 3: Bayesian phylogenetic inference under mixed models. Bioinformatics 2003, 19, 1572-1574. [CrossRef]

123. Rambaut, A. FigTree Tree Figure Drawing Tool Version 131, Institute of Evolutionary 623 Biology, University of Edinburgh. Available online: http:/ / treebioedacuk/software/figtree/ (accessed on 20 August 2021).

124. Vu, D.; Groenewald, M.; Szöke, S.; Cardinali, G.; Eberhardt, U.; Stielow, B.; de Vries, M.; Verkleij, G.J.M.; Crous, P.W.; Boekhout, T.; et al. DNA barcoding analysis of more than 9000 yeast isolates contributes to quantitative thresholds for yeast species and genera delimitation. Stud. Mycol. 2016, 85, 91-105. [CrossRef]

125. Rivera, F.N.; Gómez, Z.; González, E.; López, N.; Rodríguez, C.H.H.; Zúñiga, G. Yeasts associated with bark beetles of the genus Dendroctonus erichson (Coleoptera: Curculionidae: Scolytinae): Molecular identification and biochemical characterization. In Proceedings of the Third Workshop on Genetics of Bark Beetles and Associated Microorganisms, Asheville, NC, USA, 20 May 2006; pp. 45-48.

126. Sitepu, I.; Enriquez, L.; Nguyen, V.; Fry, R.; Simmons, B.; Singer, S.; Simmons, C.; Boundy-Mills, K.L. Ionic liquid tolerance of yeasts in family Dipodascaceae and genus Wickerhamomyces. Appl. Biochem. Biotechnol. 2020, 191, 1580-1593. [CrossRef] [PubMed]

127. Schoch, C.L.; Robbertse, B.; Robert, V.; Vu, D.; Cardinali, G.; Irinyi, L.; Meyer, W.; Nilsson, R.H.; Hughes, K.; Miller, A.N.; et al. Finding needles in haystacks: Linking scientific names, reference specimens and molecular data for fungi. Database 2014, 2014, bau061. [CrossRef] [PubMed]

128. Kurtzman, C.P.; Robnett, C.J. Phylogenetic relationships among yeasts of the "Saccharomyces complex" determined from multigene sequence analyses. FEMS Yeast Res. 2003, 3, 417-432. [CrossRef]

129. Wang, Y.; Ren, Y.C.; Zhang, Z.T.; Ke, T.; Hui, F.L. Spathaspora allomyrinae sp. nov., a D-xylose-fermenting yeast species isolated from a scarabeid beetle Allomyrina dichotoma. Int. J. Syst. Evol. 2016, 66, 2008-2012. [CrossRef]

130. Barnett, J.A. A history of research on yeasts 2: Louis Pasteur and his contemporaries, 1850-1880. Yeast 2000, 16, 755-771. [CrossRef]

131. Cavicchioli, R.; Ripple, W.J.; Timmis, K.N.; Azam, F.; Bakken, L.R.; Baylis, M.; Behrenfeld, M.J.; Boetius, A.; Boyd, P.W.; Classen, A.T.; et al. Scientists' warning to humanity: Microorganisms and climate change. Nat. Rev. Microbiol. 2019, 17, 569-586. [CrossRef] [PubMed] 
132. Jain, P.K.; Purkayastha, S.D.; De Mandal, S.; Passari, A.K.; Govindarajan, R.K. Effect of climate change on microbial diversity and its functional attributes. In Recent Advancements in Microbial Diversity; De Mandal, S., Bhatt, P., Eds.; Academic Press: San Diego, CA, USA, 2020; pp. 315-331.

133. van der Putten, W.H. Climate change, aboveground-belowground interactions, and species' range shifts. Annu. Rev. Ecol. Evol. Syst. 2012, 43, 365-383. [CrossRef]

134. Wookey, P.A.; Aerts, R.; Bardgett, R.D.; Baptist, F.; BraThen, K.A.; Cornelissen, J.H.C.; Shaver, G.R. Ecosystem feedbacks and cascade processes: Understanding their role in the responses of Arctic and alpine ecosystems to environmental change. Glob. Change Biol. 2009, 15, 1153-1172. [CrossRef] 